\title{
A Typology of Tools for Building Sustainability Strategies
}

\author{
Ruth Kaufmann-Hayoz, Christoph Bättig, Susanne Bruppacher, Rico Defila, \\ Antonietta Di Giulio, Peter Flury-Kleubler, Ueli Friederich, Myriam Garbely, Heinz \\ Gutscher, Christian Jäggi, Maya Jegen, Hans-Joachim Mosler, André Müller, \\ Nicole North, Silvia Ulli-Beer, and Jürg Wichtermann ${ }^{1}$
}

This chapter introduces and describes a typology of policy instruments that has a dual purpose. It serves (1) as a conceptual tool for integrating the findings of the different studies that were part of our inter-and transdisciplinary research and (2) as a useful frame of reference for political actors when choosing appropriate sets of instruments for policy strategies. The instruments we have included in the typology focus on the ecological dimension of sustainability; they are applied primarily to promote environmentally responsible action. However, we believe that the five basic types of instruments - command and control instruments, economic instruments, service and infrastructure instruments, collaborative agreements, and communication and diffusion instruments - are of a general character that would allow for the inclusion of specific groups of instruments for promoting economic and social sustainability. Future work will tackle the issue of complementing the typology so that it covers the full range of instruments available for promoting all three dimensions of sustainable development. The chapter consists of five sections.

After a brief introduction, we present an overview of the typology by characterising the five types of instruments and relating them to each other (section 2, including the trilingual survey Tables 1A-C on pages 40-45). In section 3, we describe the specific instruments of each type in detail and give illustrative examples. A preliminary comparison and evaluation of the different instrument types is given in section 4, while section 5 relates the typology to other classifications and typologies developed in several disciplines.

1 The responsibility for this chapter lies with the Synthesis Group (compare the chapter by DEFILA AND DI GiULIO in the Conclusions section). The Synthesis Group is grateful to Peter Flury-Kleubler, Hans-Joachim Mosler, Silvia Ulli-Beer, and Jürg Wichtermann for joining it at certain times, for offering critical comments, and for writing parts of the chapter. 


\section{Introduction}

\subsection{Aims of the typology}

The typology of instruments that we present should help us to look at classic policy instruments as well as new instruments from an actor-oriented perspective, and it should allow instruments to be evaluated with respect to issues of practical interest (effectiveness, costs, and acceptance).

Classification has always been an important methodological element in the development of the sciences. The classical procedure uses the criteria of genus proximum and differentia specifica to produce a logical system of distinctive categories. Within the social sciences, the notion of "type" has played an important role in methodological discussions, certainly since Max Weber's (1904) publications. Many of the typologies developed in the social sciences do not have the strict logic of a system of mutually exclusive classes. They are more similar to the spontaneous and fuzzy everyday classifications people use in mastering their lives. "Types" in the social sciences are usually described multidimensionally, and they serve as complex perspectives that order the social reality. Because they pertain to "natural" events (rather than to artificially made, well defined objects), there are always cases that fall between classes or that could justifiably be classified as belonging to more than one class or type. By applying the logical procedure described by Max Weber as analytical accentuation of elements of reality [pointierend hervorhebende Abstraktion], types can be constructed as "ideal types" or as "real" or "average types". Alternatively, statistical procedures, such as the discriminant function or cluster analysis can be applied to quantitative data (for a more extensive discussion of typologies of policy instruments see, for example, Kaufmann and Rosewitz, 1983, or Bemelmans-Videc et al., 1998).

Typologies or classifications differ from each other, even if they pertain to the same objects. They depend on the scientific purpose that they serve, on the goals and questions of the researcher. Therefore, no typology or classification is any more "true" than another is, but one of them might be more useful for a particular purpose. This becomes quite obvious, if we look at existing typologies of environmental policy instruments. Many were developed for the purpose of integrating a number of heterogeneous case studies in order to work out general conclusions. Others are based on specific disciplinary theories and serve the purpose of generating and testing scientific hypotheses. Still others were developed for the practical purpose of facilitating communication among policy makers. When researchers come up with a "new" typology, this does not usually mean that they consider existing ones to be wrong, but rather that they do not serve their exact purposes of study. "New" typologies often have some similarities with "old" ones, but they may make distinctions where others group things together and vice versa, or they may point out specific properties that were unimportant for earlier study purposes. ${ }^{2}$

2 In section 5 of this chapter we review some typologies and classifications that have been developed in different disciplines, and we discuss their relation to the typology that we propose. 
The dual purpose of our interdisciplinary resarch has been to study a number of different instruments available to different actors (mainly at the local level) to stimulate changes in one or more of the various factors that influence environmentally responsible behaviour and to communicate our results to those actors. We therefore needed a clearly arranged and comprehensive typology of instruments that would include all principal and politically acceptable possibilities known to influence human environmentally relevant behaviour and that would be...

- ...actor-oriented: It should reveal what instruments are available to what actors and show by what "mechanisms" the various instruments are supposed to affect the behaviour of the target groups,

- ...not restricted to specific disciplinary theories and approaches,

- ...practice-oriented: It should allow us to evaluate the instruments with respect to all practitioners' main questions: How effective are they? How much do they cost? How accepted are they?

\subsection{A word on terminology}

The notions of "strategy", "instrument", "measure", and "campaign" are not used coherently in the literature. In this volume we use them as follows:

- By "instrument" we mean the basic way in which an actor chooses to influence the behaviour of another actor (such as implementing an energy tax or presenting facts and options). We should more precisely speak of "intervention instruments", because they specify the type of intervention - the goal-directed influence of an actor upon the conditions that determine a target group's action. As the aim is not to produce effects in single individuals or organisations, but rather to affect entire populations or very large target groups, the mechanisms of the intervention instruments have to be "transported" to as many members of the target group as possible. This means that for every intervention instrument there is a specific diffusion problem that has to be resolved through the aid of special diffusion instruments. The diffusion instrument "transports", or carries, the intervention to the target group. For an intervention that bases on communication instruments in particular, the issue of how a target group can be reached effectively, quickly, and surely is central. For this reason, the diffusion problem in connection with that type of instrument will be treated in detail (see sections 2.5, 3.5, and the case study by GUTSCHER ET AL.).

- The term "measure" will be used to indicate the concrete realisation of an instrument (for example, announcing a tax of 0.3 cents per kWh non-renewable energy for a maximum duration of 15 years, or providing an information brochure on municipal waste collection to every household). Here again, intervention measures have to be complemented by diffusion measures.

- By "strategy" we mean the purposeful application of a set of instruments and measures over time in a given political-administrative context and embedded in an appropriate policy style, in order to reach a defined policy goal (such as the Strategy for Sustainable Development of the 
Swiss Federal Council (SAEFL, 1997); for an overview of other national action plans see Jänicke et al., 1999: 114).

- "Campaign" also refers to the intentional application of a whole set of instruments and measures, but the goals tend to be more specific and narrower in focus than the goals of strategies. Campaigns are usually implemented in order to achieve specific, concrete changes in behaviour, or aggregated results of behaviour changes. Campaigns that are even more specifically defined in terms of content and the temporal framework we have called "action campaigns".

\section{Overview of the typology}

We propose to distinguish five types of instruments. They are understood as "types" in the sense of complex ordering perspectives as described above, and they should not be regarded as mutually completely exclusive classes. The main dimension used to define the types is their rationale - that is, the basic psychological mechanism by which the instruments are supposed to affect the target group's behaviour.

In this section, each type is briefly described with respect to its rationale (the "mechanisms" according to which the instruments are supposed to work), the main actors (to whom the instruments are available), and the target groups (i.e., whose behaviour is intended to be influenced by the application of the instruments). In addition, some remarks are made on specific aspects of implementation and enforcement of the instruments. The entire typology is shown in the trilingual Tables $1 \mathrm{~A}-\mathrm{C}$ on pages 40-45.

\subsection{Command and control instruments}

\subsubsection{General description and rationale}

We use the term command and control instruments for regulatory instruments that are direct and mandatory (IEA, 1989). Command and control instruments in this sense are legal prescriptions that have a direct impact on the range of options open to specified social actors, because they constrain certain ways of acting or exclude some forms of conduct. Specific actions and/or specific outcomes of actions are prescribed or prohibited by way of mandatory orders. Thus, the rationale of this instrument type is based exclusively on command, control, and sanction. It is assumed that actors behave according to the prescription or norm in order to avoid penalties that take effect if they violate the norm. Therefore, such enforcement mechanisms are fundamental to the viability and effectiveness of command and control instruments. Enforcement policies rely on a variety of (conditional or secondary) instruments, ranging from license withdrawal to criminal prosecution. Enforcement measures often involve an economic component in addition to the pure regulatory aspect (e.g., fines to be paid when admissible levels of emission are exceeded; see also IEA, 1989). 


\subsubsection{Actors}

In western democracies, only the legislative authorities are legitimised to use command and control instruments. In Switzerland, federal, cantonal, or municipal authorities share this authority, the division of labour being organised according to the policy domain at issue. Although the implementation of command and control instruments may be (partly) delegated to private bodies, the final decision on their application (and eventual enforcement measures) remains with the public authorities.

\subsubsection{Target groups}

Command and control instruments can be used to influence the behaviour of any target group individuals as well as corporate actors or private companies. Basically, command and control instruments apply in the same way to every actor or group of actors specified in the legal norm.

\subsubsection{Implementation and enforcement}

The implementation and enforcement of command and control instruments can be troublesome in many respects. Often, implementation places heavy demands on technical competence as well as on the amount of available human and financial resources (Mayntz, 1980; 1983). In practice, the granting of exceptions recurrently compromises the implementation of efficient command and control instruments. In Switzerland, appealing against such granting of exceptions by the executive authorities is an uncommon practice, and the number of admitted appellants is rather limited. In some cases, moreover, legal prescriptions directed toward barely accessible target groups (such as "consumers") are very difficult to enforce, because control is almost impossible. Therefore the motive to avoid sanctions disappears (such as for illegal waste disposal by burning or dumping, or spreading manure on frozen soil).

\subsection{Economic instruments}

\subsubsection{General description and rationale}

Economic instruments are based on the assumption that environmental degradation and resource depletion occur because a substantial part of the costs of economic activities is not being paid by the actors responsible but by the general public (in the form of environmental damage, security and health risks, or long-term climatic risks). In order to correct this situation, three principal forms of intervention are conceivable:

(1) Raising the costs of polluting behaviour: This approach is based on the principle of true costs. The costs of environmentally harmful behaviour, that is, of the respective production, purchase, and investment decisions, are raised by means of incentive taxes and charges. The actors' range of options is not influenced directly; all options (production and consumption patterns, choice of technologies) remain open insofar as they are not constrained by regulations. The actors' behaviour is supposed to be steered toward environmentally sound actions, because these are more 
cost efficient. Moreover, the market mechanisms guarantee that, in order to achieve environmental goals, the least expensive measures are realised first.

(2) Reducing the costs of environmentally sound behaviour: Instead of raising the costs of environmentally undesirable behaviour, environmentally beneficial behaviour can be rewarded. By means of subsidies, prices for environmentally responsible behaviour are lowered, to the effect that such behaviour becomes more likely.

(3) Establishing markets for polluting rights: A market for the trading of resource use permits (such as the permit to pollute the air by nitrogen oxides) is created. Whoever wants to use environmental resources has to buy the respective permit on these markets.

\subsubsection{Actors}

Economic instruments are usually implemented by public authorities. They require a legal basis and can be implemented at all political levels (federal, cantonal, municipal), depending on the domain and respective authority.

\subsubsection{Target groups}

Direct target groups are firms and investors as well as private persons and households. In households, economic instruments target consumption behaviour. For companies, economic instruments make environmentally sound production more competitive. The price relations between different options (higher or lower emission levels, more or less energy intensity, more or less transport) are modified in favour of the environment. Indirectly, economic instruments usually affect all actors. For example, a tax on certain emissions will alter the price of products in the affected industrial sectors as well as their demand for other production factors. This can have effects on all other industrial sectors, on the prices of consumer and investment goods, and, of course, on foreign trade. Besides these price effects, the effects on the social distribution of wealth have to be taken into consideration, especially from a political point of view. Economic instruments affect the incomes of different actors not only through the modification of prices, but also through the way in which the government uses the taxes or finances the subsidies.

\subsubsection{Implementation and enforcement}

The implementation of economic instruments first and foremost raises the issue of their legal basis. If they are supported by existing constitutional bases, the questions of who is to be taxed, what is to be taxed, how the tax is to be calculated, and how tax revenue will be used will be defined at the level of the law. For successful implementation, it is particularly important that regulations be simple and flexible. Experience in many countries has shown that simple and uniform calculation bases that allow for little administrative interpretation are less vulnerable to manipulation and dispute (De Clercq, 1996).

Monitoring and enforcement are crucial to successful implementation of the instruments. The effort involved can vary widely. For example, a country like Switzerland, which imports all of its 
fossil fuels, can add a carbon dioxide tax to existing taxes and collect it through the customs authorities. For other harmful emissions, individual instruments for measurement and control have to be developed, which can lower public acceptance of the instruments.

For political acceptance of instruments that produce revenue, the way the revenue is used will be definitive. As a rule, redistributing the revenue to the public or using it in a targeted fashion to support environmental goals will increase acceptance (OECD, 1997a).

\section{3. $\quad$ Service and infrastructure instruments}

\subsubsection{General description and rationale}

Service and infrastructure instruments are goal-directed transformations of services or infrastructure for the promotion of certain behaviours. The term services refers to actions of individuals or organisations that enable or support other actors to achieve their goals. For example, a man who cares for an ailing father-in-law enables him to have his basic needs fulfilled and to stay alive, a hairdresser enables her clients to look nice, a fair-trade organisation enables consumers to support local farmers in developing countries: they all provide services. The term infrastructure denotes man-made, mobile or immobile physical objects that shape the actor's scope of opportunities for action. The bicycle that parents give to their daughter for her trip to school, a railway line, or a parking space are examples of infrastructure.

The existence of services and infrastructure determines to a large extent what actions are objectively possible or not for certain actors. If there is no bridge across a wide river, most people cannot cross it; if no travel guides offered their services, only very few Europeans would consider travelling to Africa or Tibet; if there was no health care system, people could not have their blood pressure checked regularly. In addition, the design and quality of services and infrastructures influence the salience of action possibilities and their potential to provide experiences of pleasure, excitement, healthiness, or security. For example, taking local trains late at night, where there are no train attendants apart from the driver in his cab and only a few passengers to inspire mutual confidence, can be unpleasant, frightening, and even dangerous.

Therefore, the rationale of this type of instrument is that by modifying services and infrastructure, desired actions can be made possible and undesired ones can be excluded, and that desired action possibilities can be made more salient and pleasant and undesired ones less salient and less pleasant. Environmentally relevant modifications of services or infrastructure can be attraction based (offering or improving environmentally sound products, services, and infrastructure that allow or facilitate environmentally sound action), or repulsion based (withdrawing products, reducing services, or degrading infrastructure that allow or facilitate ecologically desirable action). 
Table 1A: A typology of policy instruments for sustainable development.

\begin{tabular}{|c|c|}
\hline \multicolumn{2}{|c|}{ COMMAND AND CONTROL INSTRUMENTS } \\
\hline $\begin{array}{l}\text { Environmental quality standards (impact } \\
\text { thresholds and standards) } \\
\text { Emission standards } \\
\text { - best available technology } \\
\text { - prescriptive technology standard } \\
\text { Product standards and regulations for } \\
\text { the use of pollutant substances } \\
\text { - restriction, rationing, or prohibition } \\
\text { - product standards }\end{array}$ & $\begin{array}{l}\text { Licensing } \\
\text { - licence to construct } \\
\text { - } \quad \text { licence to operate } \\
\text { Liability regulations }{ }^{1} \\
\text { - } \quad \text { strict liability } \\
\text { - } \quad \text { comersal of the burden of proof } \\
\text { Zoning } \\
\text { - land use regulations } \\
\text { - } \quad \text { nater protection areas } \\
\text { nature conservation zones }\end{array}$ \\
\hline \multicolumn{2}{|c|}{ ECONOMIC INSTRUMENTS } \\
\hline $\begin{array}{l}\text { Subsidies } \\
\text { - } \quad \text { grants } \\
\text { - } \quad \text { soft loans } \\
\text { - } \text { guarantees } \\
\text { - compensation for foregoing use of the } \\
\text { resource } \\
\text { Incentive taxes } \\
\text { - taxes on energy/resources } \\
\text { - } \quad \text { taxes on emissions } \\
\text { Charges } \\
\text { - one-time charge for connection to } \\
\text { - } \quad \text { recurvices } \\
\text { - charges on advantages (value-added } \\
\text { - contribution) } \\
\text { prepaid disposal fees }\end{array}$ & $\begin{array}{l}\text { Deposit-refund systems } \\
\text { Market creation } \\
\text { - } \quad \text { joint imple allowances or permits } \\
\text { Incentation } \\
\text { - rewards } \\
-\quad \text { lotteries } \\
-\quad \text { contests/benchmarking } \\
-\quad \text { discounts }\end{array}$ \\
\hline
\end{tabular}

1 Liability regulations are often classified as economic instruments.

2 These instruments - although not usually described as economic instruments - are placed here, because from the target group's perspective their rationale is the same as in the other economic instruments (see text for further explanations). 
(Table 1A, cont.)

\section{SERVICE AND INFRASTRUCTURE INSTRUMENTS}

\section{Service instruments}

- offering or improving ecologically sound products

- withdrawing environmentally undesirable products

- offering or improving services that allow or facilitate ecologically sound action

- reducing services that allow or facilitate environmentally undesirable action
Infrastructure instruments

- offering or improving infrastructure that allows or facilitates ecologically sound action

- dismantling or degrading infrastructure that hinders or inhibits ecologically sound action

\section{Collaborative Agreements}

Public-private agreements

- agreements on prepaid disposal fees on specific product groups

- agreements on consumption goals or standards

- formal agreements with individual companies

\section{Certifications and labels}

- with legal compliance

- without legal compliance

\section{COMMUNICATION AND DIFFUSION INSTRUMENTS}

\section{Communication instruments without a} direct request

- presenting facts

- presenting options

- presenting appraisals, goals, and norms

- providing experience of reality

- presenting model behaviour

- giving feedback and enabling selffeedback

\section{Communication instruments with a} direct request

- persuading about facts

- persuading about options

- persuading about goals, appraisals, and norms

- sending appeals

- presenting prompts and reminders

- stimulating self-commitment

\section{Diffusion instruments}

- establishing direct personal contact

- establishing contact via person-to-person media

- establishing contact via mass media 
Table 1B: Typologie der Instrumente für eine nachhaltige Entwicklung.

\begin{tabular}{|c|c|}
\hline \multicolumn{2}{|c|}{ GeBote UND Verbote } \\
\hline $\begin{array}{l}\text { Umwelt-Qualitäts-Standards } \\
\text { (Immissionsbegrenzungen) } \\
\text { Emissionsbegrenzungen } \\
\text { - nach bestem Stand der Technik } \\
\text { - gemäss zwingender technischer } \\
\text { Vorschrift } \\
\text { Vorschriften für den Umgang mit } \\
\text { umweltgefährdenden Stoffen und } \\
\text { Produktestandards } \\
\text { - Beschränkungen, Rationierungen oder } \\
\text { - Verbote } \\
\text { Produktestandards }\end{array}$ & $\begin{array}{l}\text { Bewilligungspflichten } \\
\text { - Baubewilligung } \\
\text { - Betriebsbewilligung } \\
\text { - Verkaufsbewilligung } \\
\text { Haftungsrechtliche Vorschriften }{ }^{1} \\
\text { - Gefährdungshaftung } \\
\text { - Umkehr der Beweislast } \\
\text { - Obligatorische Haftpflichtversicherung } \\
\text { Raumwirksame Vorschriften } \\
\text { - Baurechtliche Ordnungen (Nutzungspläne) } \\
\text { - Gewässerschutzzonen }\end{array}$ \\
\hline \multicolumn{2}{|c|}{ MARKTWIRTSCHAFTLICHE INSTRUMENTE } \\
\hline $\begin{array}{l}\text { Subventionen } \\
\text { - à-fonds-perdu Beiträge } \\
\text { - Steuererleichterungen } \\
\text { - Darlehen/Zinsvergünstigungen } \\
\text { - } \quad \text { Bürgschaften } \\
\text { - Abgeltung für Nutzungsverzicht } \\
\text { Lenkungsabgaben } \\
\text { - Abgaben auf E nergie/Ressourcen } \\
\text { - Abgaben auf Emissionen } \\
\text { - Abgaben auf Produkte/Prozesse } \\
\text { Gebühren und verwandte Abgaben } \\
\text { - Einmalige Anschlussgebühren } \\
\text { - Wiederkehrende Benütungsgebühren } \\
\text { - Vorzugslast (Mehrwertbeitrag) } \\
\text { - Vorgezogene Entsorgungsgebühren }\end{array}$ & $\begin{array}{l}\text { Pfandsysteme } \\
\text { Einrichtung von Märkten } \\
\text { - handelbare Zertifikate/ } \\
\text { - Lizenzen/Konzessionen } \\
\text { Joint Implementation } \\
\text { Punktuelle Anreize im Rahmen } \\
\text { von Aktionen und Kampagnen } \\
\text { - Belohnungen } \\
\text { - Lotterien } \\
\text { - Wettbewerbe/Benchmarking } \\
\text { - Rabatte }\end{array}$ \\
\hline
\end{tabular}

1 Haftungsrechtliche Vorschriften werden oft den marktwirtschaftlichen Instrumenten zugeordnet. 2 Wir ordnen diese Instrumente - obwohl nicht marktwirtschaftliche Instrumente im üblichen Sinne hier zu, weil ihr grundlegender Wirkmechanismus aus der Perpektive der Zielgruppe derselbe ist wie bei den andern ökonomischen Instrumenten. 
(Table 1B, cont.)

SERVICE- UND INFRASTRUKTURINSTRUMENTE

Serviceinstrumente

- Bereitstellung oder Verbesserung umweltschonender Produkte

- Rückzug umweltbelastender Produkte

- Bereitstellung oder Verbesserung von Dienstleistungen, die umweltschonendes Handeln ermöglichen oder erleichtern

- Abbau von Dienstleistungen, die umweltbelastendes Handeln ermöglichen oder erleichtern
Infrastrukturinstrumente

- Bereitstellung oder Aufwertung von Infrastrukturen, die umweltschonendes Handeln ermöglichen oder erleichtern

- Rückbau oder Abwertung von Infrastrukturen, die umweltschonendes Handeln verhindern oder erschweren

\section{VEREINBARUNGEN}

Vereinbarungen zwischen Staat und Wirtschaft

- Vereinbarung über die Belastung bestimmter P roduktegruppen mit einer vorgezogenen Entsorgungsgebühr

- Vereinbarung von Verbrauchs-Zielwerten oder Normen

- Verträge mit einzelnen Unternehmen

\section{Zertifizierungen und Labels}

- mit legaler Übereinstimmung

- ohne legale Übereinstimmung

KOMMUNIKATIONS- UND DIFFUSIONSINSTRUMENTE

Kommunikationsinstrumente ohne direkte Aufforderung

- Sachverhalte darstellen

- Möglichkeiten darstellen

- Bewertungen, Ziele und Normen darstellen

- Realität erfahrbar machen

- Modellverhalten zeigen

- Feedback geben und Selbstfeedback ermöglichen

\section{Kommunikationsinstrumente mit} direkter Aufforderung

- von Sachverhalten überzeugen

- von Möglichkeiten überzeugen

- von Bewertungen, Zielen und Normen überzeugen

- Appelle aussenden

- Hinweise und Gedächtnishilfen anbieten

- Selbstverpflichtung anregen

\section{Diffusionsinstrumente}

- Direkten persönlichen Kontakt herstellen

- Kontakt über Person-zu-Person-Medien herstellen

- Kontakt über Massenmedien herstellen 
Table 1C: Typologie des instruments pour un développement durable.

\begin{tabular}{|c|c|}
\hline \multicolumn{2}{|c|}{ INSTRUMENTS RÉGULATIFS } \\
\hline $\begin{array}{l}\text { Normes de qualité environnementale } \\
\text { (seuils d'impact et standards) } \\
\text { Normes d'émission } \\
\text { - meilleure technologie disponible } \\
\text { Règlementation technique obligatoire } \\
\text { tòglements d'utilisation de substances } \\
\text { toxiques et normes de produits } \\
\text { - } \quad \text { normitations, rationnement ou interdictions } \\
\text { normes de produits }\end{array}$ & $\begin{array}{l}\text { Autorisations obligatoires } \\
\text { - } \quad \text { autorisation de construction } \\
\text { - } \text { autorisation d'exploitation } \\
\text { - } \text { autorisation de mise en vente } \\
\text { Réglementation de la responsabilité } \\
\text { civile } \\
\text { - responsabilité à raison du risque } \\
\text { - renversement de la charge de preuve } \\
\text { - } \quad \text { assurance responsabilité civile obligatoire } \\
\text { Règlements de planification } \\
\text { - } \quad \text { plans d'utilisation et d'affectation des sols } \\
\text { - zones de protection des eaux } \\
\text { - zones naturelles protégées }\end{array}$ \\
\hline \multicolumn{2}{|c|}{ INSTRUMENTS ÉCONOMIQUES } \\
\hline $\begin{array}{l}\text { Subventions } \\
\text { - contributions à fond perdu } \\
\text { - } \text { allégements fiscaux } \\
\text { - } \text { prêts et taux d'intérêts avantageux } \\
\text { - } \text { cautions } \\
\text { d'utommagement pour renoncion de ressources } \\
\text { Taxes incitatives } \\
\text { - taxes sur l'énergie et les ressources } \\
\text { - taxes sur les émissions } \\
\text { - taxes sur les produits et processus } \\
\text { Redevances } \\
\text { - redevances uniques de raccordement } \\
\text { - redevances périodiques d'utilisation } \\
\text { - redevances sur des avantages } \\
\text { - } \text { (contribution à la valeur ajoutée) } \\
\text { redevances (avancées) d'élimination }\end{array}$ & $\begin{array}{l}\text { Système de dépôt } \\
\text { Création de marchés } \\
\text { - certificats/licences/concessions } \\
\text { échangeables } \\
\text { - joint implementation } \\
\text { Incitations ponctuelles dans le cadre de } \\
\text { campagnes d'action } \\
\text { - récompenses } \\
\text { - loteries } \\
\text { - concours/benchmarking } \\
\text { - rabais }\end{array}$ \\
\hline
\end{tabular}

1 Les réglementations de la responsabilité civile sont souvent classées parmi les instruments économiques.

2 Ces instruments - bien qu'ils ne soient pas des instruments économiques au sens usuel - sont classés ici parce que, dans la perspective des acteurs visés, leur mécanisme d'action fondamental est le même que celui des autres instruments économiques (cf. explications dans le texte). 
(Table 1C, cont.)

\section{INSTRUMENTS DE SERVICE ET D'INFRASTRUCTURE}

\section{Instruments de service}

- offre ou amélioration de produits écologiques

- suppression de produits nocifs

- offre ou amélioration de services permettant ou facilitant un comportement écologique

- réduction de services permettant ou facilitant un comportement néfaste à l'environnement

\section{Instruments d'infrastructure}

- offre ou revalorisation d'infrastructures permettant ou facilitant un comportement écologique

- réduction ou dévalorisation d'infrastructures empêchant un comportement écologique

\section{ACCORDS LIBREMENT CONSENTIS}

Accords entre l'État et l'économie

- accords sur des redevances d'élimination avancées pour des groupes de produits

- accords sur des standards et des valeurs cibles de consommation

- accords formels avec certaines entreprises

\section{Établissement de certificats et de labels}

- avec conformité légale

- sans conformité légale

\section{INSTRUMENTS DE COMMUNICATION ET DE DIFFUSION}

\section{Instruments de communication sans} sollicitation directe

- présenter des faits

- présenter des options

- présenter des évaluations, des buts et des normes

- fournir l'expérience de la réalité

- présenter des modèles de comportement

- donner du feedback et permettre l'auto feedback

\section{Instruments de communication avec}

\section{sollicitation directe}

- persuader sur des faits

- persuader sur des options

- persuader sur des évaluations, des buts et des normes

- envoyer des appels

- offrir des indications et des rappels

- inciter à l'auto engagement

\section{Instruments de diffusions}

- établir un contact personnel direct

- établir un contact au travers d'un média de personne à personne

- établir un contact au travers des massmédias 


\subsubsection{Actors}

Service and infrastructure instruments can be applied by private companies (public transportation firms, retail business companies, and so on), public authorities, or non-governmental organisations (NGOs), but also by individuals and informal groups. Public authorities are usually in control of the quantity and quality of most transport infrastructures (roads, railways, airports), while private companies decide what products to offer and how to present and market them. In private life, voluntary services provided to others and decisions on the purchase of household appliances and vehicles can be regarded as service and infrastructure instruments.

\subsubsection{Target groups}

Service and infrastructure instruments are often targeted to the general public. However, they may also aim at specific professional or lifestyle groups, or at groups defined by some common behaviour, e.g., cyclists or wine drinkers.

\subsubsection{Implementation and enforcement}

The setting up and modification of large infrastructures and public services, e.g., in the transportation or energy sector, usually require political decisions and often also corresponding legal bases. Therefore, service and infrastructure decisions may constitute hot political issues. On the other hand, more subtle forms of service and infrastructure instruments may be implemented very easily (the setting up of an adequate infrastructure for waste separation in households and communes, or the offering of home delivery services by a grocery store, for example). The attraction based forms of service and infrastructure instruments have the advantage of being easily accepted by the target persons. Travelling by train because it is comfortable and fast is perceived much more positively than travelling by train because there is no alternative. The repulsion based forms (such as the reduction of parking space) often meet as much resistance as command and control instruments and taxes or charges, because they are felt to restrict personal freedom and autonomy.

\subsection{Collaborative agreements}

\subsubsection{General description and rationale}

Collaborative agreements are legally binding or non-binding commitments by the private sector or parts of it (industrial sectors, their associations, or individual companies) made towards the government to enhance energy and resource efficiency or greenhouse gas abatement in sectors that are traditionally not regulated by public policy. Frequently, the environmental targets are defined through lengthy negotiations between the private sector and the government. The government may in turn forego the definition of environmental targets through statutes or detailed regulations. Formal, i.e., legally binding, agreements often have a regulatory component, and they are usually situated in a context of national or even international conventions (e.g., the UN Framework Convention 
on Climate Change, or the EU/UN Air Pollution Convention). However, in the international context no sanctions have been introduced so far. These conventions thus constitute only a moral obligation.

The rationale of legally binding collaborative agreements may come close to that of regulatory instruments, and sometimes the price mechanism is used in a way very similar to that in economic instruments. A clear distinction between the categories is not always possible. For example, agreements that are made under the pressure of subsidiary state interventions and use the price mechanism for promoting the desired behaviour may be regarded as economic instruments. But in comparison with authoritative state interventions, collaborative agreements contain - because of the importance of negotiations in reaching the agreements - an element of self-regulation of the actors involved. According to Dente (1995: 17), it is exactly this potential for self-regulation that needs to be explored further in the search for new environmental policy instruments (see also Glasbergen, 1998, for an in-depth analysis and evaluation of public-private agreements).

Collaborative agreements can also be distinguished from voluntary actions, such as those elicited by the Swiss government's "Energy 2000" Action Programme, which we treat as a set of communication and diffusion instruments. ${ }^{3}$ In those cases there are no formal mutual obligations or mandates; they can consist in unilateral declarations about certain goals or programmes and concrete actions to be performed.

\subsubsection{Actors and target groups}

The actors involved are usually the government and parts of the private sector (the "polluters"); the target group itself participates as a partner in developing and implementing the instrument. An agreement can take the form of a mandate to follow certain objectives and programmes or to take certain measures in specific domains. Agreements can also be worked out between private organisations, such as between consumer and producer organisations, or between umbrella organisations and business and trade associations (BFE, 1998a; 1998b). In such cases, one party of the "iron triangle" of environmental policy (government, polluters or target group, and environmental organisations) has been left out. Such "private-private agreements" usually lead to the development of a label or a certification.

\subsubsection{Implementation and enforcement}

Although collaborative agreements have a touch of "voluntarism", the industries taking part in such agreements are generally put under slight pressure to participate. The threat of more restrictive statutes and regulations, if the environmental goal cannot be achieved by collaborative agreements, forces the industries to define the goals together with the government.

In Switzerland, there has been only limited experience with legally binding agreements in the environment sector. There have been several successfully implemented agreements with single in-

3 For a description of this programme, see the chapter by BÄTTIG AND BALTHASAR. 
dustries regarding the introduction of prepaid disposal fees (glass, aluminium cans, refrigerator or electronic scrap recycling). Other agreements, such as negotiations with the printing and graphic arts industry regarding targets for volatile organic compounds (VOC) emissions, have failed. In the energy sector the government was successful in signing an agreement with the electrical appliances industries that set targets for energy efficiency standards. The negotiated targets have also been integrated into the Ordinance on Energy Use. Negotiations with automobile importers on fuel consumption failed. The government thereafter issued regulations on fuel consumption targets (Bättig, 2001).

\subsection{Communication and diffusion instruments}

\subsubsection{General description and rationale}

Communication instruments aim at influencing the actors' internal conditions of action, especially their goals (their "preferences" in terms of economic theory), their knowledge, and their behaviour programmes. By influencing "mental skills" as well as "motor skills" of individuals, they also affect the social relations and communicative processes among different actors. The rationale of these instruments is that behaviour changes require a modification of the motivational, cognitive, and social preconditions of action, and that this can be achieved by stimulating the thinking of individuals and by shaping societal discourses on goals and options for action. ${ }^{4}$

Because the aim is not to affect single individuals, but rather to achieve blanket effects penetrating large groups, the interventions must be "transported" to affect the target groups through the aid of diffusion instruments. Diffusion is a problem that all instruments entail, but with communication instruments it is a special problem, because implementation of a communication instrument does not make any sense at all unless combined with a diffusion instrument (see the study by GUTSCHER ET AL.).

Typically, two phases of diffusion can be distinguished. In a first phase, initial diffusion is reached through the aid of targeted diffusion instruments. The second phase is one of self-diffusion, in which the contents spread either directly from person-to-person within the social surround of the primary target group or by means of the traditional mass media. An example of person-toperson dissemination is the passing along of particularly illuminating arguments - supporting participation in a boycott, for example - within the direct circles of family or workplace. Diffusion through the social surround can also be promoted specifically through concrete instructions and

4 In the literature, the term "persuasive instruments" is sometimes used (e.g. Dahme and Grunow, 1983). It has a more restricted meaning than our definition of communication and diffusion instruments, because it usually refers only to a few selected instruments to influence knowledge. Another frequently used term is "social marketing". Social marketing refers to the activities of non-commercial organisations in planning, organising, realising, and controlling. These are activities that aim - directly or indirectly - to solve a social task and/or to disseminate social ideas or behaviours within a community (Kotler, 1978; Kotler and Roberto, 1991; Geller, 1989; Prose et al., 1994). 
activities. An important example is the building and management of networks. In the area of sustainability strategies, for instance, networks represent an important intermediate goal that can be achieved through communication and diffusion instruments. Self-diffusion through the effects of the mass media on its own, finally, also plays a role when the successful initial diffusion is itself a media event. This occurred in September 2000 in France, when the media gave coverage to the blockades of oil refineries and service stations that were organised all over the country as a reaction to increases in the price of petrol.

\subsubsection{Actors}

Communication and diffusion instruments are available to public authorities, to the entire educational system from kindergarten to the university level, to providers of continuing education as well as to all other actor groups, especially to the media, NGOs, informal social movements, private companies, and to individuals, especially to parents and teachers. The use of communication and diffusion instruments in private life is up to individuals or informal social groups. For instance, it is up to parents to decide what they want their children to know about environmental issues and how they will try to motivate them to behave in certain ways. However, public actors can try to influence the private use of communication and diffusion instruments by using communication and diffusion measures themselves. So, in a first step, private actors may be the target group of communication instruments applied by public actors, and in a second step, they may themselves be the actors. The use of communication instruments by teachers or the media can be influenced to some extent by public authorities, by using command and control or service instruments. On the other hand, private actors can use communication and diffusion instruments to put pressure on public authorities or on private companies to take certain actions.

\subsubsection{Target groups}

Communication instruments can be targeted at the general public, at specific professional or lifestyle groups, or at groups defined by some common behaviour, such as car drivers or tourists. Children and young people are often regarded as highly promising target groups. Target groups can also be companies, associations, or public authorities.

\subsubsection{Implementation and enforcement}

The use of communication instruments is indicated mainly in early phases of the implementation of strategies. One of the strengths of communication instruments lies in the fact that initial effects can be achieved relatively quickly, in contrast to creating legal bases for the implementation of classic instruments, which can entail years of political process. For this reason, it makes sense to use communication instruments to prepare the way for further intervention instruments.

Using communication instruments to complement other instruments is also generally indicated. The success of traditional types of instruments depends to a large part on the implementation of these instruments and their effects. Of course, not knowing about command and control instru- 
ments does not protect people from sanctions, and it is hardly possible to escape the economic effects of price changes. But still, it is communications about the instruments that cause a large extent of their effects, because people will take care not to perform certain actions or will plan and execute alternative actions ("announcement effect"). In this way, the effects of classical instruments can be reinforced and optimised. These reinforcing effects also base upon the fact that in addition to the mechanisms of classical instruments, communication instruments promote insight into, understanding about, and the legitimacy of external measures.

In principle, communication instruments - like the other instrument types - can be used for any purpose. Therefore, within a society an ethical discourse about tolerable communicated contents is necessary. This discourse is itself a communication instrument on a meta-level. As a result of such a discourse, command and control instruments can be applied in order to prevent harmful forms of communication. Every legal system is likely to contain regulations pertaining to contents that may not be legally expressed publicly in words or images. For example, the Swiss penal code prohibits the distribution of ideologies that are based upon systematic discrimination of racial or ethnical groups. Similar regulations exist with regard to pornography. Restrictions of advertising for cigarettes or alcohol are additional examples of controlling communicated contents. For promoting sustainable development as well, society may have to set careful norms to control the communication of certain ecologically dangerous contents.

Public discourse is also necessary on tolerable behaviour and - especially with regard to the young - on the topic of the various ways that behaviour is trained. Not always do training opportunities have socially or ecologically desirable effects. For example, allowing people to learn to drive contributes to a growth of motor transport. Grossman and DeGaetano (1999) claim that realistic video games with the imitation guns sometimes used allow players to practice shooting in a realistic way. They develop shooting skills that can be applied when holding a real weapon in hand for the very first time. This explains the horribly high success rate of children who are given a single opportunity to use a fire weapon after chronic video game training. Of course, not all trained behaviours will be performed in everyday situations. However, the likelihood that they will be performed rises with training. As with the control of communicated contents, every society and legal system has to limit and control training opportunities that are likely to lead to hazardous consequences with regard to social sustainability. To achieve this, communication instruments have to be combined with command and control instruments.

\section{Detailed description of the instruments}

Within each of the five types of policy instruments, a number of sub-types can be distinguished. Tables 1A-C (pages 40-45) provide a trilingual survey of the entire typology and the distinctions we make in each of the five classes. In sections 3.1 through 3.5 below, we will explain and describe these types and sub-types in more detail and give illustrative examples for some of them. 


\subsection{Command and control instruments}

\begin{tabular}{|l|l|}
\hline \multicolumn{2}{|c|}{ COMMAND AND CONTROL INSTRUMENTS } \\
\hline $\begin{array}{l}\text { Environmental quality standards (impact } \\
\text { thresholds and standards) }\end{array}$ & $\begin{array}{l}\text { Licensing } \\
\text { Emission standards }\end{array}$ \\
$\begin{array}{l}\text { - licence to construct } \\
\text { - pest available technology }\end{array}$ & - licence to operate \\
$\begin{array}{l}\text { Product standards and regulations for the } \\
\text { use of pollutant substances }\end{array}$ & Liability regulations \\
- restriction, rationing, or prohibition & - strict liability \\
product standards & reversal of the burden of proof \\
& compulsory third party liability insurance \\
& Zoning land use regulations \\
\hline
\end{tabular}

The distinctions we make within the command and control type of instruments are based on a classification developed by the International Energy Agency (IEA) of the Organisation for Economic Co-operation and Development (OECD) (IEA, 1989), which focuses on energy policy, but is highly relevant to other environmental policy domains. The IEA typology has been slightly adapted and illustrated by examples from Swiss environmental policies.

\section{Example 1: \\ Regulatory measures to reduce polluting emissions of heating systems}

Since the 1980s, the Swiss federal government has actively pursued a policy to reduce the emission of pollutants from heating systems. This policy was tightened in the 1992, revised Ordinance on Air Pollution Control. The programme bases upon three measures, which are regulatory in nature.

Emission thresholds: In an international comparison, the regulation sets very strict threshold values for the emission of nitrogen oxide ( $\mathrm{NO}$ : $120 \mathrm{mg} / \mathrm{m}^{3}$ ) and carbon monoxide (C $0: 80 \mathrm{~g} / \mathrm{m}^{3}$ ) for heating systems up to 350 $\mathrm{kW}$.

Systems inspections: An inspection of the system type is required for combustion installations, which guarantees adherence to emission thresholds. Through compulsory licensing for construction, permits are granted only for buildings with heating systems that have passed inspection.
Heating controls: The cantons responsible for compliance with the Ordinance on Air Pollution Control appoint heating system controllers, who check the emission levels of new and existing systems.

There is general agreement that this combination of various regulatory mechanisms has definitely contributed to a reduction of polluting emissions from heating systems. An important point is that the regulations do not stop at declaring acceptable emission levels, but rather that there are follow-up measures for implementing the regulations (for greater detail, compare Balthasar and Knöpfel, 1994). Balthasar and Knöpfel (1994) show, moreover, that the regulatory programme has also had positive side effects the economy and on policies that foster innovation. 


\subsubsection{Environmental quality standards (Impact thresholds and standards)}

Environmental quality standards define "the allowable average concentrations over a specific time period for a given pollutant in a particular region" (IEA, 1989: 38). In Switzerland, this type of regulation is widely used in air policies. The Ordinance on Air Pollution Control defines impact thresholds (maximum concentrations) for nitrogen dioxide, sulfur dioxide, volatile organic compounds, ozone, and other pollutants. The Swiss experience shows, however, that such environmental quality standards are repeatedly infringed. While the standards may indicate that a level of concentration of pollutants has been exceeded, no immediate action is demanded unless a responsible party can clearly be identified. In the case of air pollution, this is often impossible because of the multitude of actors contributing to the violation of the emission impact threshold (e.g., all drivers of motor vehicles and all home-owners operating fossil fuel heating systems). If a responsible party can be identified (such as in a case of water pollution that is caused by the release of pollutant substances by an industrial company), it faces the sanctions as defined by law.

\subsubsection{Emission standards}

Emission standards "set a maximum allowable rate of pollution output for each generic type of source (transport, power plants, industry) by type of pollutant” (IEA, 1989:39). Emission standards are often closely related to technological procedures and are, for this reason, frequently referred to as technology standards, even though they do not actually prescribe the use of a particular technology. There are more flexible variants of the emission and technology standards called "best available technologies" or "best practicable means". These may help to increase the pressure to apply new technologies under an unchanged regulatory regime. The emission standards for heating systems imposed by the revised Ordinance on Air Pollution Control from 1992 in Switzerland is an example of such a regulation (see Example 1). The IEA lists another form of environmental regulation, namely the prescriptive technology standard. It defines the type of technology or method to be applied in a particular instance. Prescriptive technology standards are not widespread because of their inherent rigidity.

\subsubsection{Product standards and regulations for the use of pollutant substances}

Product standards define the quality, that is, the admissible concentration of certain substances that has to be met by any product produced and/or sold on the market. In Switzerland - as in many other OECD countries - product standards are used widely to regulate fuel quality, as in the case of the proscription of leaded gasoline. The Swiss Ordinance on Air Pollution Control sets detailed quality standards for transport and heating fuel, and the Water Protection Decree prohibits the addition of phosphates to the contents of laundry detergents.

Specific requirements can be set for the use of harmful or toxic substances; they can be restricted to specific conditions, rationed, or prohibited entirely. Restriction or rationing can also be based on more general criteria. During the oil crisis in the 1970s, for instance, the Swiss authorities prohibited the use of fuel driven cars on 12 Sundays per year. 


\section{Example 2: \\ Environmental impact assessment}

In Switzerland, facilities that could have a considerable impact on the environment may be constructed and operated only if environmental impact has been assessed and approved through an official procedure. The assessment is required for an extensive range of facilities: transportation facilities, such as highways; harbour facilities; railway lines and airports; energy production plants; waste disposal facilities; military facilities, such as weapons ranges; tourist and recreational facilities; but also mainly industrial facilities that have a potentially negative environmental impact.

For assessment of environmental impact, a report must first be submitted. In particular, the report must describe the measures that are planned in order to protect the environment and describe environmental impacts that will occur despite these measures. The reports must fulfil very high standards with respect to content. For this reason, they are prepared as a rule by specialised experts. For large projects, this requires a great deal of effort and expense. This is notable, because it is the person or organisation that seeks to realise the project that must submit the report.
Reports are then examined by the authorities and serve - together with other information, such as petitions by environmental protection agencies or other experts - as a basis for the decision on whether the project satisfies environmental provisions and may thus be approved. Frequently, environmental impact assessments must be co-ordinated with other licensing procedures (for example, water conservation authorisations or land clearing grants).

Mandatory environmental impact assessments have been in effect in Switzerland since 1985. Following their introduction, there were initial complaints that the instrument placed too lengthy delays on the projects or halted them all together. Since then, criticism has largely ceased, not least because the authorities undertook various efforts to speed up the procedure. Today, as a necessary step in the planning of large projects, environmental impact assessments have become self-understood.

\subsubsection{Licensing}

In general, licensing is not used as an independent instrument, but rather to support the implementation of regulatory standards. Three types of licenses can be distinguished: licences to construct,

\section{licences to operate, and licences to sell.}

Licences are of importance in the siting of new facilities. In most Swiss cantons, the license to build new housing facilities is bound to compliance with various impact thresholds and, less often, emission standards. The builder has to demonstrate that the building meets the terms of the SIA380-1-norm ${ }^{5}$. As regards insulation, this norm is the benchmark corresponding to the prescription of the "best available technology". Furthermore, the builder has to prove that the heating system has no important negative impact on the environment (regarding fixed environmental standards). If the requirements are not fulfilled, an environmental impact assessment is mandatory. This proce-

5 The SIA-380-1-norm is a recommendation edited by the Swiss Association of Engineers and Architects (SIA). It is used as a planning tool for energy efficient construction with respect to the maximal heating need per surface and the minimal heat rate. The norm by itself is not legally binding, but various cantons implement it as a binding guideline in their cantonal laws, mostly at the ordinance level. 
dure is designed to guarantee that environmental quality standards are respected or, at least, not violated disproportionately during the construction and operating of new facilities (see Example 2).

Technical licensing procedures must be followed to obtain a licence to sell. This licensing is important to the implementing of product and/or emission standards. As described above in Example 1, Swiss environmental law prescribes a technical licensing procedure for heating systems up to $350 \mathrm{~kW}$. This procedure serves primarily to check whether the system on the market is in accord with the legal emission thresholds. Technical licensing procedures are also prescribed for cars.

\subsubsection{Liability regulations ${ }^{6}$}

Whoever suffers damages must carry them. This old, general principle remains valid in Swiss law as well as in most European legal systems. Increasingly, however, the principle is being overturned through the creation of legal bases that hold the person who causes the damage liable to payment of compensation (the polluter-pays principle). Even in areas where there is a liability basis, the person causing the damage is usually liable only if blame can be established. If and only if it can be proved that the damaging party can be charged with fault, or in other words, if the damage occurred through negligence or intent, can there be a liability claim. The fact that the person suffering the damages as a rule must prove that the accused party is guilty often hinders the enforcement of rights to compensation.

Strict liability: Liability is tightened in areas where a particular facility or particular behaviour involves special risks. The legal system makes the provision in such areas that the originator of damages - for example, the operating authority of a factory that pollutes water - will be held liable even if it has undertaken all possible measures to avoid damage. This type of liability is independent of misconduct. The fact alone that people have created risk makes them responsible for any damage that arises. For this reason, such instruments are called strict liability or liability regardless of fault. Swiss environmental law includes strict liability (for example, special strict liability for nuclear plants or pipelines). If a special danger to the environment - ground, water, air - results from the operations of a company or plant, the owners are liable for damages if the risk becomes reality. Liability, however, is restricted to damage incurred to persons or property. In contrast, there is no liability provision that applies in the case of so-called damage to the environment alone - damage to the air, water, or wild plants and animals (with the exception of fish). Other countries extend liability for environmental damage much further than Switzerland.

Reversal of the burden of proof: In the case of normal liability for fault as well, the law can make provisions that facilitate the enforcement of claims by the injured party. Here it is not, as in the usual case, the injured party who must prove that the damaging party is guilty of fault, but rather the wrongdoer must prove that he is in fact blameless. However, reversal of the burden of

6 Liability regulations are often classified as economic instruments, especially by economists. In our interdisciplinary Synthesis Group, arguments were exchanged between lawyers and economists, and the Synthesis Group finally decided to list them with the command and control instruments. 
proof is not significant in environmental law, because here liability regardless of fault usually applies. Legal systems in other countries sometimes make provisions for reversal of the burden of proof, or causation presumption, with regard to causation issues (a connection between operations of a facility and the onset of environmental damage).

Compulsory third party liability insurance: Environmental damage can in some cases be very expensive. In such situations the most stringent laws concerning liability will be of no use, if the damaging party cannot pay damages because he is insolvent. For this reason, for various, particularly risk-laden areas, liability laws make the provision that the owners of facilities and installations must be insured. In theory, compulsory insurance against liability (or comparable liability provisions) may be required for any area. In practice, however, certain risks are hardly insurable (for example, the risks incurred by refuse collection centres, or landfill, often show up after long periods of time have elapsed and are extremely difficult to appraise).

\subsubsection{Zoning}

Zoning laws regulate the admissibility of conduct in certain geographical areas. The content of the laws may be positive or negative, in that they may admit, or even prescribe, certain activities for one area that are prohibited in other areas or rule out activities that are approved elsewhere. In the area of zoning laws, a number of instruments can have a direct or indirect effect on sustainable development:

Land use regulations represent the most important category of zoning laws. The regulations aim to reduce environmental damage particularly in sensitive areas by, for example, separating industrial and business zones from residential zones or recreational areas. In this sense, the regulations are nothing more than a spatial differentiation, or specification, of emission and environmental quality standards. In combination with licensing procedures, zoning should help to ensure that certain levels of pollution control are achieved. At the same time, zoning can achieve spatial concentration of environmentally damaging activities, and thus shortened transport distances, which reduces emissions.

Water protection areas are designed to prevent pollution of ground water that is used to gain drinking water. They serve in the full sense of the word to protect the environment at the source.

Nature conservation zones serve special environmental concerns and efforts, such as protection of rare or endangered animal or plant species. 


\subsection{Economic instruments}

\begin{tabular}{|c|c|}
\hline \multicolumn{2}{|c|}{ ECONOMIC INSTRUMENTS } \\
\hline $\begin{array}{l}\text { Subsidies } \\
\text { - } \quad \text { grants } \\
\text { - } \quad \text { tax allowances } \\
\text { - } \quad \text { goft loans } \\
\text { - } \quad \text { compensantees } \\
\text { resource } \\
\text { Incentive taxes } \\
\text { - } \quad \text { taxes on energy/resources } \\
\text { - } \quad \text { taxes on emissions } \\
\text { - } \quad \text { taxes on products/processes } \\
\text { Charges } \\
\text { - } \quad \text { one-time charge for connection to services } \\
\text { - } \text { recurrent charges for use } \\
\text { - charges on advantages (value-added } \\
\text { - } \quad \text { prentribution) }\end{array}$ & $\begin{array}{l}\text { Deposit-refund system } \\
\text { Market creation } \\
\text { - tradable allowances or permits } \\
\text { - joint implementation } \\
\text { Incentives as parts of action campaigns } \\
\text { - rewards } \\
\text { - lotteries } \\
\text { - contests/benchmarking } \\
\text { - discounts }\end{array}$ \\
\hline
\end{tabular}

As mentioned above in the general description of economic instruments in section 2.2., there are three principal ways to intervene: (1) reduce the costs of environmentally sound behaviour, (2) raise the costs of pollutant behaviour, and (3) establish markets for polluting rights. We distinguish two groups of instruments by which the costs of environmentally sound behaviour are reduced (subsidies and incentives as parts of action campaigns), two groups of instruments that raise the costs of pollutant behaviour (incentive taxes and charges), and a group of instruments for the creation of markets for polluting rights. Deposit refund systems are treated as a group of its own.

Raising the costs of pollutant behaviour can be achieved by public taxation. Taxes comprise all payments imposed one-sidedly by sovereign authority of the government upon taxable persons. Taxation has to be legislation-based. Because of this requirement, in some cases taxes can be introduced only after a lengthy political decision making process. There are several categories of taxes. In terms of purpose, they can be divided into incentive taxes and charges. Incentive taxes aim to achieve efficient environmental protection by making detrimental practices expensive enough that there is an adaptation reaction and a change in practices. "Pure" incentive taxes are not levied in order to create government revenue (fiscal function), but rather to steer environmental practices via price adjustments. Charges represent recompense for special public services or special advantages.

\subsubsection{Subsidies}

Companies and households receive financial support from the government for environmentally sound practices. Financial subsidies can be granted by the federal government (FG), the canton 
(C), or the municipality (M) and, depending upon amount and application area, must be approved by parliament or even by public vote. Increased or changing demand for these investment goods can also have an indirect effect on other economic sectors. Such effects may be one of the explicit goals of investment through subsidies. For instance, the Decree on Energy Investment within the Energy 2000 Action Programme has the aim of promoting energy-efficient building and renovation and giving new impetus to the economy.

\section{Example 3: \\ Government subsidisation of wastewater disposal}

In the last 25 years, the Confederation has massively subsidised investments in wastewater disposal by municipalities and associations (approximately $17 \%$ of the total investment). In addition to the federal government, the cantons have also granted subsidies. In sum, subsidies by the cantons totalled more than the government grants. Subsidisation has achieved the following results:

(a) Increased tempo effect: Expert opinion rates the incentive effect of subsidies on the willingness of municipalities and associations to build wastewater treatment facilities as strong. Without the subsidies, the current status of water protection could not have been achieved.

(b) Compensation effect: S ubsidy levels were set according to the financial capacity of the cantons or municipalities. This resulted in indirect financial compensation. (c) Decrease in wastewater treatment costs and subsidisation problems: With subsidies, wastewater treatment costs went down. This meant that polluters were not paying the full cost of disposal of wastewater. As the polluterpays principle for a number of environment areas became anchored and gained widespread acceptance, government and canton subsidies were cut drastically. This presented a new challenge particularly to the municipalities, which now had to remediate or rebuild expensive wastewater infrastructure without the financial aid of government or canton. In some municipalities, over $90 \%$ of wastewater investments had been subsidised by government and canton. This led, in exceptional cases, to a situation where wastewater infrastructure had been created that the municipalities could not, in the long term, finance themselves (see the chapters by MÜLLER AND KRAMER and the comment by FRIEDERICH; ECOPLAN, 1993).

Grants are non-reimbursable contributions, that is, outright financial aid from the government. Grants may also be called subsidies in the narrowest sense of the word. ${ }^{7}$ Examples include the Energy Investment Programme in the framework of the Energy 2000 Action Programme (C), investment grants to freight traffic facilities (C), to public transport services in municipalities (C), to wastewater treatment facilities $(\mathrm{FG}, \mathrm{C})$, and subsidisation of the remediation of public buildings $(\mathrm{C}$, M) (see also Example 3).

Tax allowances: Environmentally acceptable practice is rewarded through tax advantages. This can be achieved by special tax deductions on general income tax or by special tax rates. Some ex-

7 In Germany and France, only contributions of this type are called subsidisation. Tax allowances and loans then fall into the general category of "financial assistance by the government". The Swiss use of the term corresponds more closely to English usage, where "subsidies" comprises both non-reimbursable financial assistance by the government (grants) and tax allowances and loans. 
amples are tax deductions for the use of renewable energy sources and for investments in improving the energy efficiency of buildings $(\mathrm{C})$, or reduced tax rate for solar power installations (see Example 4).

\section{Example 4: \\ Tax allowances for energy measures in Switzerland}

Since the late 1970s, more and more cantons have created the opportunity to deduct energy investments from income tax. Since 1995, the federal taxation authorities have granted a generous tax deduction for energy investments for privately owned properties. Tax deductions are very popular politically, but the environmental gains have been extremely modest:

(a) The tax deductions for energy measures are little known - only $27 \%$ of property owners are familiar with the allowable deductions. (b) In $70 \%$ to $80 \%$ of cases, property owners would have implemented the energy measures even without tax deductions. The so-called "cash-in" effect is therefore considerable. A shortfall in tax revenue of 50 to 100 million Swiss francs annually does not constitute positive energy effects.

(c) The cost reduction effect of the tax deduction is strongly dependent upon income level. Households with high incomes profit most from the tax deduction. This differential price reduction effect is justified neither from the perspective of the polluter nor from the perspective of efficient energy policy (ECONCEPT and IPSO, 1997).

Soft Loans: This form of financial assistance is a repayable loan at much more favourable conditions, at very low or nil interest, than on the capital market. An example is a loan provided by the Swiss cantons to companies for purposes of instituting measures to prevent wastewater production.

Guarantees: If the government guarantees credits extended to an actor for the financing of environmentally sound measures, the actor can arrange for credit at more favourable conditions. Capital costs can be kept low. For example, the cantons may extend credit guarantees to companies to finance measures to prevent wastewater.

Compensation for foregoing use of a resource: Rather than penalising environmentally damaging practices (through environmental taxes) or prohibiting them (through laws and statutes), environmentally sound practices can also be promoted by paying the polluter to desist. Usually the environmental polluter is ordered to desist from the practices at least in part. Polluters are thus not completely free in their decision to take compensation rather than to continue to pollute. In this case, financial compensation takes on the character of a reimbursement for lost profits or ensuing costs, and the political motivation is social distribution. The lines are fuzzy in this area, and it is also not always possible to make a clear distinction between compensation and subsidies. As a rule, in practice the instrument mutates to reimbursement or subsidy. No true market arises. Some examples in agriculture include reimbursement for establishing ecological buffer land, compensation for improvement measures in the area of water inflow, water adits, and cachments. 


\subsubsection{Incentive taxes}

Incentive taxes aim to achieve efficient environmental protection by offering price-based financial incentives, causing those who have to pay for the impact they have on the environment to adapt and change to more environmentally sound practices.

Taxes on energy and resources: The justification for taxing resources is that shortages of the resources (such as soil or drinking water) are not reflected adequately in market prices. The assumption is that market prices do not mirror the needs of future generations or of the third world. With regard to energy taxes, the problem of environmental pollution provides an additional argument. Examples: drinking water tax (C), tax on gravel (C), energy tax, electricity tax (C).

Taxes on emissions: Emissions taxes proper have to be linked directly to the polluting emissions (for example, through measuring wastewater volume). For enforcement to be realisable, however, taxes are frequently levied on certain products that are known to make a clear contribution to emissions. The line drawn between taxes on emissions and taxes on products is fluid. Examples: wastewater tax (C), VOC tax, $\mathrm{CO}_{2}$ tax, $\mathrm{NO}_{\mathrm{x}}$ tax on combustion installations, noise-related landing tax at airports (see also Example 5).

Taxes on products and processes: With the product taxes, tax is levied on products that cause environmental degradation through their production, consumption, or disposal. Process taxes are levied on certain types of processing or production and, in a broader sense, on certain branches of industry. The distinction between process and product taxes is not always clear. Product and process taxes are often levied when a direct tax on emissions would be too difficult or impossible to enforce for technical reasons. Examples: distance-dependent charge on heavy goods vehicles; consumption-dependent motor vehicle tax $(\mathrm{C})$; tax on non-recyclable beverage containers; tax on fertilisers; energy efficiency tax on buildings (see the chapter by GARBELY AND MCFARLANE).

\subsubsection{Charges}

Charges [Kausalabgaben] are recompense for certain services or advantages provided publicly to private persons. These charges are based on the concept of quid pro quo, a thing given as compensation (by private persons) in return for services (public).

One-time charge for connection to services: This is a charge for connection to public services, such as public utility systems. The idea is that persons served by the service should buy into the existing infrastructure system. Examples: service connection charge for electricity, gas, longdistance heating from a district heating system; service connection charge for sewer services.

Recurrent charges for use: These are charges for continual use of public infrastructure facilities. They are often made up of a fixed amount (annual basic charge) and a variable, consumptiondependent amount (sometimes called the "working price" or "quantity charge"). Examples: waste disposal charges (M); charge for wastewater treatment; public utility charge for water (M). (see the chapter by MÜLLER AND KRAMER)

Charges on advantages (value-added tax): These are charged for the (potential) economic advantage enjoyed by a private person that stems from public institutions. In contrast to the charges 
for connection to services, VAT is not dependent upon actual use of the advantage. Example: property-owner charge for the street that provides access to the property.

Pre-paid disposal fees: These fees are not paid when the public service (disposal) takes place, but rather in advance at the time of purchase. For example, there are pre-paid disposal fees for refrigerators and batteries.

\section{Example 5: \\ Incentive tax on volatile organic compounds in Switzerland}

With the year 2000, Switzerland has become the first country to fight ground level ozone with an incentive tax on volatile organic compounds (VOC, also known as hydrocarbons). The tax level is substantial, as is the expected contribution to reduction in the use of substances containing VOC. Furthermore, redistribution of the revenue on a per-capita basis makes the tax highly innovative.

Together with nitrogen oxides, VOC contribute to the excessive formation of ozone near ground level. The Swiss Air Pollution Control Strategy's reduction targets for ground-level ozone were exceeded in past years. The excessive impact of VOC damages public health and the environment and must be reduced through a corresponding reduction of emissions. To keep within the impact thresholds, $\mathrm{VOC}$ emissions have to be reduced by $70-80 \%$, i.e., by at least 70,000 tons annually.

To fight ground-level ozone emissions, the Swiss Federal Assembly adopted the Amendment of the Environmental Protection Law (EPL) and brought it into force on $1 \mathrm{~J}$ uly 1997. The Ordinance on incentive taxes on VOC based on Articles $35 \mathrm{a}$ and $35 \mathrm{c}$ of the EPL dates from 12 November 1997 and can be regarded as the first implementation of an effective incentive tax in Switzerland. Even though emission reduction targets are similar in the EU, the tax on VOC in S witzerland is the first of its kind in the world.
Starting on $1 \mathrm{~J}$ anuary 2000 , a tax on VOC is levied upon volatile organic substances such as solvents, paints and varnishes, glues, and cleaning materials. To meet a claim submitted by industrial representatives, a stepwise introduction of the tax is outlined. The Ordinance sets a rate of $2 \mathrm{CHF}$ per $\mathrm{kg}$ VOC until 2002 and an increased tax of $3 \mathrm{CHF}$ per $\mathrm{kg}$ VOC from 2003 on.

Only VOC emitted in Switzerland should be taxed. Levying the tax on import and on production in Switzerland means that VOC that are not emitted into the environment, or those that are exported, are exempted. Furthermore, the Federal Council may grant exemption from the tax to companies that have already reduced VOC emissions well beyond the legal requirements, to the extent of the additional costs incurred.

The incentive tax is expected to generate net revenues of 160 million CHF per year between 2000 and 2002 and 210 million CHF per year from 2003 on. The law requires that the revenue be distributed equally among all members of the population through the mandatory health insurance programme. Health insurance is simply being used as the administrative channel to distribute the monies; this model does not subsidise health insurance premiums. To maintain transparency, premiums and the VOC deduction will be shown clearly on insurance policies or accounts for premiums.

\subsubsection{Deposit-refund systems}

A deposit is added to the price of potentially polluting or resource consuming products. When pollution or resource consumption is avoided by returning these (often reusable) products, a refund of the deposit follows. In Switzerland, most existing deposit-refund systems are the result of negotiations. 


\subsubsection{Market creation}

Environmental polluting can be traded on markets. For this, there has to be an at least implicit definition of ownership rights to environmental resources. A polluter has to buy, for example, a license from the owner of the environmental goods (the government). If ownership rights to environmental goods are extended to the polluter, the polluter will demand recompense for discontinuing the polluting practices.

Tradable allowances or permits: Here the total acceptable extent of environmental impact (pollution standard) is established. The polluter has to acquire the necessary certificates. Often certificates are implemented in combination with emission standards: provided that polluters do not reach the prescribed emission allowances, they may "bank" their "credits" or sell the allowance in excess of their own needs to other facilities or industries. In this way, certificates can be traded, and the price is the result of supply and demand. Examples: Tradable emission allowances or certificates for water pollution or air pollution; individually transferable fishing quotas. The Kyoto Protocol to the United Nations Framework Convention on Climate Change (UNFCCC) provides for emissions trading, i.e., the trading of $\mathrm{CO}_{2}$ emissions between two countries that have committed to reduce emissions.

Flexible financial mechanisms under the Kyoto Protocol to the United Nations Framework Convention on Climate Change (UNFCCC): With flexible mechanisms, such as Joint Implementation, industrialised countries can finance measures towards greenhouse gas (GHG) abatement in developing countries and countries in transition. The reduced greenhouse gas emissions abroad are banked into the account of the industrialised country towards its commitment under the Kyoto Protocol to reduce GHG emissions. The pilot phase of Joint Implementation Activities Implemented Jointly (AIJ) - was finalised in 2000; JI will probably start only in 2008. Clean Development Mechanisms (CDM) was begun in 2000.

\subsubsection{Incentives as parts of action campaigns}

The main target group of such incentives is consumers. These instruments are usually not included among economic policy instruments. But from the point of view of the target group, they rely on the same mechanism as subsidies. They reduce - temporarily - the price of environmentally sound goods relative to conventional ones in an attempt to influence the consumers' purchase decisions. The incentives can be distinguished from subsidies as follows: Subsidies are classical instruments of financial support of companies and/or households by the state, and a formal political decision is required for their implementation. Usually such support is provided with a medium or long-term perspective (months or years). In contrast, the incentives as described below are provided as parts of campaigns or other well defined programmes, they are usually rather small in amount, and they are often provided by actors other than public authorities, especially by private enterprises or organisations. Their main goal is to stimulate people to rethink their usual routines and to encourage them to try new products or behaviours. The assumption is that after the incentive campaign has ended, people will maintain their new behaviours. The immediate goal of such incentives may also 
be to successfully introduce new, resource efficient technologies or products on the market and to accelerate their diffusion.

Rewards: People who act in desired ways or achieve a particular behavioural goal receive rewards. Rewards may be financial, remuneration in kind, or symbolic, such as cash prizes, free services, parking permits, and so on. Quite common are coupons for certain actions. The coupons may be exchanged for products in certain stores, for instance. Long-term and lasting implementation of a reinforcement plan is a problem (usually unresolved). All studies show that the desired behaviour disappears as soon as rewards come to an end. This can be explained by the fact that people justify the new behaviour on the basis of the expected reward. This external justification for an action makes a change in attitudes unnecessary. The motivation for a change in behaviour comes from the outside, and there is no inner acceptance. For this reason, it is better to offer carefully apportioned, rather small rewards that by themselves alone do not cause a massive change in behaviour. Too strong external justification hinders the emergence of additional motivational and self-justification processes that are founded in a person's own thinking (Diamond and Loewy, 1991; Everett et al., 1974; Katzev and Pardini, 1987-1988). Examples: Free bus tickets to a sports stadium to people who have arrived by train; certificates, medals, or other recognition awards.

Lotteries: People who act in the desired way receive a lottery ticket. The principle here is related to the principle of rewards. The difference is that reward is not certain and will be received only with a certain probability. Even though long-term success after a lottery is no more assured than with other reward models, this method is at least an affordable alternative to widely distributed rewards, especially if the intervention is planned for a longer time period. It is important to set an ideal probability level for winning. If chances of winning are too high, an external justification has been created for the behaviour (the prize). If chances are too low, people can become frustrated due to lack of success. Ideal chances of winning would result in a prize now and then, but not often enough that winning becomes the only justification for the behaviour. Comparative studies show that the effect of expected possible rewards (lottery) is greater than that of regularly received rewards (Jacobs and Bailey, 1982-1983; Witmer and Geller, 1976). Example: a lottery ticket in every carton of eggs from free-range chickens.

Contests/benchmarking: Contests are held among persons, households, or other groups. The winner of the prize is the person or group who reaches the set goal first. All contestants should have the same chance of winning. If there seems to be no chance of winning, participation and the willingness to make an effort will drop off rapidly. A contest where the winner is established only near the end of the contest is recommended. This sustains the excitement of the contest and keeps the effort level high. As a form of intervention, contests show the same disadvantages as other rewards: The more attractive the prize, the more it will become the main cause of the behaviour change. This in turn hinders the development of a real change in underlying attitudes. If the prize is not attractive enough, only extremely achievement-oriented and competitive persons will take part. Again, it is important to find the right balance, for the main goal is the long-term establishment of a new behaviour (Witmer and Geller, 1976). Examples: The first person to reach an energy-saving 
goal, or the person who saves the most energy in a certain period of time, wins the prize; solar power prizes for municipalities.

Discounts: Temporary price reductions for environmentally sound products may be offered by retailers or producers in order to draw consumers' attention to the products and to make them more attractive relative to conventional products. In special cases, sellers themselves may benefit from the increased diffusion of such products. For instance, it may be more profitable for a public electricity utility to sell energy-saving household appliances at a discount price than to buy and sell additional amounts of electricity.

\section{3. $\quad$ Service and infrastructure instruments}

\begin{tabular}{|l|l|}
\hline \multicolumn{2}{|c|}{ SERVICE AND INFRASTRUCTURE INSTRUMENTS } \\
\hline $\begin{array}{l}\text { Service instruments } \\
\text { offering or improving ecologically sound } \\
\text { products } \\
\text { withdrawing environmentally undesirable } \\
\text { products } \\
\text { offering or improving services that allow or } \\
\text { facilitate ecologically sound action } \\
\text { reducing services that allow or facilitate } \\
\text { environmentally undesirable action }\end{array}$ & $\begin{array}{l}\text { Infrastructure instruments } \\
\text { offering or improving infrastructure that } \\
\text { allows or facilitates ecologically sound } \\
\text { action } \\
\text { dismantling or degrading infrastructure that } \\
\text { hinders or inhibits ecologically sound action }\end{array}$ \\
\hline
\end{tabular}

Service and infrastructure instruments are goal-directed transformations of services or infrastructure for the promotion of certain behaviours. They can be used in order to make desired actions possible, more salient, or more pleasant, or to exclude undesired actions or to make them less salient and less pleasant. Environmentally relevant modifications of services or infrastructure can be attraction based (offering or improving environmentally sound products or services and infrastructure that allows or facilitates environmentally sound action), or repulsion based (withdrawing products, reducing services, or degrading infrastructure that allows or facilitates environmentally undesirable actions).

\subsection{1. $\quad$ Service instruments}

Services are actions of individuals or organisations that enable or support other actors to achieve their goals. A service may consist in offering a physical product for sale, in providing information or guidance, in offering special skills, and so on.

Offering or improving ecologically sound products: A common barrier to environmentally responsible purchase behaviour is the unavailability of respective products, their lower quality in terms of aesthetics or convenience, and the lack of reliable information about their environmental 
quality. Therefore, improving the quality of such products, improving their accessibility, and reducing the uncertainty about their environmental qualities will increase their attractiveness. Example: Offering organically grown food at or very near the places where people do their daily shopping, displaying it in an attractive way, and taking care that taste and visual appearance are at least as good as in conventionally produced food.

Withdrawing environmentally undesirable products: A retailer may discontinue to offer certain environmentally undesirable products, thus making them impossible to buy. Example: A drugstore discontinues the sale of body care products that have been tested on animals.

Offering or improving services that allow or facilitate ecologically sound action: Using public transportation is in general less damaging to the environment than travelling by car. However, it is often less comfortable, and it can even be distressing. Overcrowded trams are neither pleasant nor healthy. Travelling in a nearly empty suburban railway car with a few drunken youngsters who are smoking in the non-smoking compartment, without any attendants who could provide assistance, can even be intimidating. For economic reasons, the number of attendants at railway stations and in trains has been cut drastically in recent years. This has led to a deterioration of the service quality of public transportation. On the other hand, improving public transportation by attractive rolling stock, ample seating, and a train staff that cares about passengers would make travel by train more pleasant and healthy and would thus facilitate the consumer's choice of the environmentally better alternative. A further example: Car sharing organisations offer an attractive service that makes it easy for people to get rid of their own cars without suffering a loss of personal mobility (see also Example 6).

\section{Example 6: \\ Encouraging car-pooling: the CARLOS project}

With the CARLOS project, an innovative transportation option is being designed and tested in the region of Burgdorf in the Germanspeaking part of Switzerland. Car-los is a play on words, for in German it means "car-less", i.e., to have no car. The project aims to build a pick-up system on the basis of private automobiles in thinly settled regions that have limited access to public transportation. The system is a kind of highly developed hitchhiking system. Special car stops form the core of the new services and infrastructures. The car stops are equipped with an electronic display board that shows approaching cars where a potential passenger would like to go. Women may signal on the board that they wish to be picked up by women only. The users activate the display board by paying a small fee into a meter.
They receive a ticket that they hand to drivers who stop to provide a lift. Drivers can use these tickets as gift certificates, lottery tickets, or similar things. Video cameras record the automobile, license number, time of departure, and destination. The new services and infrastructures offered are meant to be taken over by public transportation providers in future in order to provide a denser network of transportation routes in areas with limited public transportation. CARLOS allows people to be more mobile without owning cars, while it at the same improves the poor occupation ratio of vehicles. In regions where regulations give priority to highly occupied vehicles (HOV) - i.e., on certain roads and in parking areas CARLOS represents a useful complement to such measures. (Hasler and Wälti, 1999) 
Reducing services that allow or facilitate environmentally undesirable action: Christmas shopping flights to far away destinations or heli-skiing in the Alps are ecologically quite harmful behaviours; by taking them off their programmes, tourism or travel agencies are applying a repulsion based service instrument.

\subsubsection{Infrastructure instruments}

Infrastructure means man-made, mobile or immobile physical objects that shape the actor's scope of action possibilities. Physical aspects of the environment influence human behaviour very directly by encouraging certain behaviours (Kaufmann-Hayoz et al., 1996).

Offering or improving infrastructure that allows or facilitates ecologically sound action: Whether a certain service, e.g., an additional train in the evening rush hour, can be offered, also depends on the infrastructure. It may be that additional trains to supply more seats can only be introduced if more tracks are built or if the signalling installations allow shorter distances between the trains. Other examples: In many older toilet models, the entire contents of the toilet tank empty with every flush. Water-saving behaviour would be possible if there were an interruption button or if toilets were so constructed that one flush would empty only part of the water in the tank (in most cases sufficient). Only with repeated pushing of the flushing handle would the toilet empty the entire tank.

\section{Example 7: \\ New design of main roads in town centres: The "Bern Model"}

In Switzerland, many national highways go directly through town centres that grew up historically. In the centres, there are restaurants, shops, and the like on these roads. In past decades, some of these roads were enlarged to accommodate multiple-lane traffic. In many towns, 20,000 cars a day pass through, and during rush hours traffic jams hold up public buses and trams. This produces not only air and noise pollution detrimental to public health, but has other negative effects on the quality of life and the well being of residents and visitors to the centres. The roads cut the town centres in two, and pedestrian crossings are dangerous and involve long waits. $P$ avements in front of restaurants and shops are small and uninviting to pedestrians. Bicyclists are endangered by the heavy traffic that takes over the whole of the road.
The "Bern Model" is a modern traffic-planning concept that seeks to correct the negative consequences of previous design decisions and, at the same time, to create options for future developments.

On the basis of participatory planning processes, structural measures appropriate to the traffic situations are realised to reach the desired goals (Kobi et al., 1995). The "Bern Model" was applied to redesigning the Seftigenstrasse in Wabern near Bern. Structural measures (roundabout, centre lane, bicycle lane, enlargement of pavements and pavements in front of shops) succeeded in enlarging the space for pedestrians and bicyclists and making it more attractive (the number of pedestrians and bicyclists increased). At the same time, traffic flowed more steadily, so that emissions were reduced (Haefeli et al., 2000, Tiefbauamt des Kantons Bern, 2000). 


\section{Dismantling or degrading infrastructure that hinders or inhibits ecologically sound}

action: As long as there are plenty of free parking spaces in a city and traffic runs smoothly, a large proportion of people will not use public transportation, even if it maintains high standards. By delimiting the capacity or quality of the road infrastructure, the relative attractiveness of public transportation increases. Other examples: The availability of a clothes dryer in a household invites residents to use it; removing it would constitute a repulsion based infrastructure measure (see also Example 7).

\subsection{Collaborative agreements}

\begin{tabular}{|l|l|}
\hline \multicolumn{2}{|c|}{ Collaborative AgreEmENTS } \\
\hline $\begin{array}{l}\text { Public-private agreements } \\
\text { agreements on prepaid disposal fees on } \\
\text { specific product groups } \\
\text { agreements on consumption goals or } \\
\quad \begin{array}{l}\text { standards } \\
\text { formal agreements with individual } \\
\text { companies }\end{array}\end{array}$ \\
\hline
\end{tabular}

Collaborative agreements are legally binding or non-binding commitments of the private sector or parts of it (industrial sectors, their associations, or individual companies) to the government to enhance energy and resource efficiency or greenhouse gas abatement in sectors that are not regulated by public policy. An important part of the agreements are the negotiations about the targets to be achieved. ${ }^{8}$

\subsubsection{Public-private agreements}

These are legally binding commitments by single enterprises, industry associations, or full branches to achieve jointly defined environment and climate targets at a certain point in time so that the government does not have to implement the threat of regulations and law. This does not necessarily require an agreement between the government and all the market partners. An agreement with the market leader(s) may suffice, as the announcement effect of such agreements is considerable. Additionally, it is necessary in any case to carry out further (flanking) measures by the government or the industries (such as informing customers) in order to guarantee the agreement's successful implementation.

8 More detailed overviews of different types of collaborative agreements in OECD countries are given in IEA (1997) and OECD (1999). 
Agreements on prepaid disposal fees for specific product groups: Technically seen, this is a charge in the sense of economic instruments. If the charge is finalised through negotiations between the concerned industries or importers and the government, this charge can be called a collaborative agreement. In turn, the government foregoes the introduction of more compelling instruments. Examples of this policy process have been the recycling of glass, aluminium cans, PET bottles, batteries, and refrigerators.

\section{Example 8: \\ The large-scale consumer model in the canton of Zurich (legal compliance model for large-scale consumers)}

The new energy law of the canton of Zurich allows large-scale consumers, singly or groupwise, to make a commitment to the canton to increase their energy efficiency. In return, the canton exempts large-scale consumers from detailed regulations. With this new execution regulation, large-scale consumers may choose the most economic way to achieve the energy targets, and by doing so they gain more flexibility. For reasons of efficiency, agreements with groups of large-scale consumers are desirable. By the end of 1999, four groups had signed agreements with the canton of Zurich:

- In mid-1997 eleven four- and five-star hotels together with the Kongresshaus (the socalled "Convention Pool") committed to increasing their energy efficiency within the next 20 years by $27 \%$.

- The Airport of Zurich decided in 1998 to enter into a 10-year agreement.

- By the end of 1998, 12 enterprises working together in the framework of the Zurich Energy Model committed to increasing their energy efficiency by 2007 by $15 \%$.
- The "Group 4" constitutes a holding with headquarters in the United States. The holding is not allowed to join any group, and therefore a separate agreement with the canton had to be signed. The holding is also not allowed to publish any sensitive data.

The canton of Zurich foresees to expand the agreements to include a possible thousand large-scale consumers in the canton.

The quantitative impact on energy efficiency gains of this large-scale consumer model can not yet been assessed. Not enough time has elapsed, and enterprises are participating only voluntarily. Initial experiences, though, indicate that the agreement allows an additional, operationally still profitable energy efficiency potential to be realised. Success factors for the large-scale consumer model include a costeffective impetus to participation from outside the enterprise, clear target negotiation, intensive communication between the parties to the agreement, stringent control and sanction mechanisms, and the implementation of an internal energy management system.

Agreements on consumption goals or standards: The Swiss Decree on Energy Use and its implementing provisions in the Ordinance on Energy Use provide for joint definition of consumption goals regarding plants and equipment by government and concerned organisations. Negotiations between the government and branches of trades not only define target consumption, but also the time period in which these goals are to be achieved. For such agreements to succeed, it is essential that the agreed upon goals are not softened with time, but are continuously intensified. Examples of successful negotiations are the agreements on consumption goals for electrical household and office appliances. A negative example is the failure of the negotiations between the Swiss government and importers of cars and other actors (Swiss Touring Club, automotive trade associa- 
tion) on consumption goals for fuel. Following the failure of these negotiations, the Swiss government enacted an ordinance ${ }^{9}$ in 1995 , which prescribes a reduction of the fuel consumption of new cars by $15 \%$ within five years.

Formal agreements with individual companies: In the framework of the execution of energy regulations, a few cantons foresee the possibility of agreements with individual large-scale consumers or groups of large-scale consumers in order to oblige them to fulfil specific targets. In return, the canton foregoes the introduction of detailed energy regulations.

\subsubsection{Certifications and labels}

Labels and certifications can guarantee compliance with legal environment standards (inclusive of control) or can even go beyond these legal standards. If the standards are not fulfilled, however, the government cannot impose sanctions. Labels are product oriented environmental standards. The processes behind the product do not necessarily have to be environmentally friendly. Certifications are enterprise or organisation related labels that show that the enterprise's premises and its production processes aim towards environmental quality. Certifications do not stand for the quality of single products, but rather certify that the environmental impacts of the whole production and life cycle process are documented and controlled.

\section{Example 9: \\ ISO 14001 certification}

The ISO 14001 norm certifies an environment management system that aims to reduce energy consumption and environmental impacts by constantly upgrading the processes of production, product design, provision, disposal, and services. The environment targets have to be clearly defined. Continuous and systematic monitoring and documentation of the processes have to provide evidence of the efforts. Not the government, but independent, privately accredited certification institutions periodically check compliance with the targets (in Switzerland about six institutions exist, such as SQS, SGS Group, TÜV Thun). ${ }^{10}$ The certificate ISO 14001 is not put on the certified enterprise's products, but it can be used for purposes of marketing and advertisement on company stationery, for instance. In 1999 approximately 340 enterprises in Switzerland had obtained certification under the 14001 norm.

With legal compliance: Certifications and labels with legal compliance have to guarantee compliance with legal environment standards (inclusive of control by the government). Such products and processes are promoted, supported, and subsidised by the government. Examples: a label

9 Verordnung über die Absenkung des spezifischen Treibstoffverbrauchs von Personenwagen (VAT).

10 The ISO 14001 certification is not classified in the category "with legal compliance" unlike the EMAS certification, which is based on European Law and which is executed by institutions accredited and certified by the government. In addition, enterprises with EMAS certification have to sign a publicly accessible environment declaration that is not required for ISO 14001 certification. 
for organically grown food (Bio-Knospe label), for food grown by integrated production (IP label), Eco-Management and Audit Scheme (EMAS) certifications, green electricity label (see the contribution by GEHRIG AND NORTH).

Without legal compliance: Labels and certifications without legal compliance go beyond legal environment standards by setting higher environmental goals. The government does not control compliance. Conformity with law is thus a necessary but not sufficient condition. Examples: $K A G$ and agri-natura (meat), M-Sano (food), Öko-Tex (textiles), Max Havelaar (fair trade), Minergie (low energy houses) (see also Example 9).

\subsection{Communication and diffusion instruments}

\begin{tabular}{|c|c|}
\hline \multicolumn{2}{|c|}{ COMMUNICATION AND DIFFUSION INSTRUMENTS } \\
\hline $\begin{array}{l}\text { Communication instruments without a direct } \\
\text { request } \\
\text { - } \quad \text { presenting facts } \\
\text { - } \text { presenting options } \\
\text { - } \quad \text { presenting appraisals, goals, and norms } \\
\text { - } \text { providing experience of reality } \\
\text { - } \text { presenting model behaviour } \\
\text { - } \text { giving feedback and enabling self-feedback } \\
\text { Communication instruments with a direct } \\
\text { request } \\
\text { - persuading about facts } \\
\text { - } \quad \text { persuading about options } \\
\text { - } \text { persuading about goals, appraisals, and } \\
\text { - } \text { norms } \\
\text { - } \quad \text { presending appeals } \\
\text { - } \text { stimulating self-commitment }\end{array}$ & $\begin{array}{l}\text { Diffusion instruments } \\
\text { - } \quad \text { establishing direct personal contact } \\
\text { - } \quad \text { establishing contact via person-to-person } \\
\text { media } \\
\text { - establishing contact via mass media }\end{array}$ \\
\hline
\end{tabular}

Communication instruments aim at influencing the actors' internal structure, especially their knowledge, goals, and behaviour programmes. We distinguish between communication instruments that contain a direct request to adopt certain views, goals, or behaviours, and instruments that contain no such direct request. Diffusion instruments are used to "transport" an instrument to as many actors in the target groups as possible.

In ordering and describing communication and diffusion instruments, we have taken into account that here - in contrast to the other types of instruments - there are far fewer established policy instruments to be found and categorised. Moreover, some of the usual names given to communication instruments, such as "information campaign" or "advisory service", actually refer to a variety of instrument functions. Depending upon their purpose and design, for example, informa- 
tion campaigns and advisory services may simply distribute facts or also contain options, appraisals, and requests. The effects produced will vary accordingly. The decisive factor used for the typology was not the concrete design of the instruments as measures (e.g., courses and other educational offerings, advice, network formation, pilot and demonstration facilities or projects, information campaigns, and so on) and not the details of their physical and formal realisation. It is, after all, not crucial whether paper or e-mail serves as the medium. What is decisive are the functions that are thus put into effect. For these reasons, we settled on a representation that is systematic, functional, and grounded in social psychology (cf. Mosler and Gutscher, 1998). The advantage is that not only can tools be positioned that are already familiar in the world of practice, but also that functional gaps in an existing combination of instruments can be revealed. The form chosen for the typology thus also serves the needed goal of stimulating social creativity in policy strategy planning and in the development of new instruments.

\subsubsection{Communication instruments without a direct request}

Presenting facts: Facts are presented by making verbal statements about reality without presenting any appraisals and by presenting visual or auditory images (such as pictures of deforested areas in Brazil, sound recordings of the traffic noise along the Brenner motorway) and pieces of evidence (for example, an illegally shot lynx, a species protected by law in Switzerland). Since statements and images of reality are not the reality itself, they can be true or false. To deliberately make false statements about people (to slander) or non-social aspects of the world (to claim that $\mathrm{CO}_{2}$ emissions have no effect on the global climate) or to show fake images is a powerful means of social influence. For promoting sustainable development, of course, the only ethically justified statements are statements of specific, true facts.

Presenting facts influences the target persons' knowledge. This serves not only the purpose of mediating new knowledge, e.g., about ecological phenomena, such as the destruction of the ozone layer, but also of destroying false knowledge, e.g., about the seeming harmlessness of certain everyday behaviours, such as throwing batteries into household trash. Knowledge can provide target persons with new action options. Knowledge also has an effect upon individual mental skills. Facts can be presented by using a wide variety of diffusion instruments (see section 3.5.3). Examples: Newspaper reports about the melting of the polar ice caps and its causes; school lessons about the principles of climatology; publication of violations of air pollution impact thresholds.

Although the presentation of facts is a communication instrument that can be used on its own, its psychological effects (see the chapter by FLURY-KLEUBLER AND GUTSCHER) are not limited to modifications of knowledge, but also include the experience of appraisals, especially emotions. That is, the mere presentation of facts can evoke emotions, since the facts presented are evaluated by the target persons in relation to their pre-existing goals or - in other words - their values. Contents that are already associated in the target person to a certain emotion can trigger that emotion. If this happens simultaneously with the presentation of new contents, these contents will in the future be associated with the emotions triggered. Thus, appraisal of the facts presented can be influenced. 
Presenting options: Not only factual reality can be presented, but also options, or action possibilities and possible future states. Presenting how reality could be, if we so desired, and what we could do to realise it, is one of the most important ways of influencing the thought and action of others. Examples: Describing scenarios of the development of road traffic depending on different economic, political, social, or technological decisions; pointing out how household waste can be reduced or energy can be saved in the private home.

Presenting appraisals, goals, and norms: In general, the presentation of facts or options is accompanied by appraisals. Every appraisal refers to a certain mental content and implies goals, since it is always at least implicitly related to a goal. Besides knowledge, goals are a second key target of communication instruments. Like influencing knowledge, influencing goals also has an effect upon behaviour, because goals have both an appraisal function and a motivation function. Therefore, they influence how we interpret stimuli and how we act in a situation. If goals are very general and (relatively) stable in time, we can call them values. If they refer to human mental activity or behaviour, it is common to call them norms. We have to distinguish prescriptive and descriptive norms. The first refer to what thought or behaviour is supposed to be, the latter to how performance really is. Norms shared by several individuals are social norms.

Appraisals can be expressed and experienced in two forms. First, they can be experienced as verbal concepts. Second, they can have the phenomenal quality of emotions. Within a target person, the presentation of appraisals can trigger both verbal concepts and emotions. Communication instruments can allow people to categorise certain facts using verbal labels. But they can also trigger emotions; they can evoke fear or joy. Fear appeals are among the most efficient communication instruments, if properly designed. They should not only trigger fear, but also provide concrete, detailed, available, and efficient coping actions (Leventhal, 1970: 157f.). In addition, overly intense negative or positive emotions disturb the ability to process information systematically (Jepson and Chaiken, 1990; Smith and Mackie, 2000: 277ff.). Appraisals are communicated not only verbally, but also by associating music or other non-verbal signs with the facts or options presented. This provides immediate clues about the relevance and positive or negative valence of an event. The potential in music is widely used, such as for propagating religious ideas, but also in advertising (cf. Zimbardo and Leippe, 1991: 250-251). Examples: A television commercial can accompany the scene of a person travelling by train with a musical sound track that is expected to trigger pleasant emotions in the target groups. In a leaflet, an appeal to avoid wearing fur products can be accompanied by photographs of suffering animals.

Communication instruments can activate pre-existing norms to strengthen their action-guiding effect. They can also transform norms or even establish new ones (Cialdini et al., 1990; Reno et al., 1993; Hopper and Nielsen, 1991). By presenting appraisals, everybody can try to set and communicate prescriptive social norms. One way of expressing them is to claim that many, most, or at least relevant people behave in a certain manner, that is, to claim the existence of a certain descriptive social norm. This means is quite popular in advertising, but also in media reports. Examples: Setting thermostats to 20 degrees $\mathrm{C}$ in sitting rooms and to 18 degrees in bedrooms; an advertise- 
ment with the message that "brains take trains"; ethical codices of specific professional groups or economic branches.

In the context of setting and communicating norms, it is also important to make sure that certain norm contents are not set or communicated. Television stations, web sites, or political communicators should not set or communicate norms that are hazardous in content. To prevent this, communication instruments can be used to a certain extent. However, if the content of a certain norm is extremely hazardous, this is also a field of command and control instruments. For instance, a topic worth discussing is whether the glorification of dangerous driving in movies should be prohibited.

Providing experience of reality: The presentation of facts can be designed so as to involve all the senses and give target persons a comprehensive experience of a certain piece of reality. One means of making the experience of realities that are to be communicated more intensive consists in moving into the situation that is the object of communication. One can go with people to the environments and objects one would like to show them. The providing of experiences of reality is also accompanied by presenting appraisals. It is often a combination of a communication instrument and a service instrument (see section 3.3), since, e.g., the moving into a situation and the guiding of people are services. Examples: A wilderness camping tour; a guided excursion to a slum, a waste dump, or a polluted beach; an open house in a low-energy house or in a wind power plant; enabling "experimental" realities in all sorts of pilot and demonstration projects (see Example 10).

\section{Example 10: \\ Light electromobiles pilot and demonstration programme}

New technologies for energy utilisation aim to reduce the damage to the environment that arises from motor vehicles. Light electromobiles (LEM) and vehicles with low emission rates, such as hybrid cars and cars running on natural gas, can become important elements in a future traffic concept that accents choosing the most energy-efficient vehicle for the particular need. The "light electromobile" pilot and demonstration programme was started in Switzerland in 1992. Within the programme, a large-scale trial was started in 1994. This largescale trial with LEM in Mendrisio and partner communities was designed to test the effects of light electromobiles on traffic and on the environment and to examine any issues pertinent to their introduction on the market. At the official opening of the trial on $23 \mathrm{~J}$ une 1995, Federal Councillor Adolf Ogi outlined its three main goals:
- Demonstrate and evaluate the appropriate implementation of LEM

- Test individual and combined measures to promote the introduction of LEM on the market

- Demonstrate the role of LEM as elements of an environmentally friendly and forwardlooking mobility concept.

Results of an accompanying study show that the large-scale trial was highly successful with regard to raising people's awareness and knowledge about this new technology. The findings reveal clearly that with increasing proximity to LEM projects, people's knowledge and evaluation of the new technology increase positively (Ulli-Beer and Haefeli, 1999). 
Presenting model behaviour: Whenever human individuals are perceivable by others or when people report about human behaviour, model learning can take place, independently of the model's intention to influence others. ${ }^{11}$ When seeing, hearing, or reading about the behaviour of another person, we can learn about the person's situation, the goals he or she pursues, what means he or she uses, and what consequences the use of those means in that situation has. Model behaviour influences our perceived descriptive norms and thus indirectly our prescriptive norms. Presenting model behaviour can be used deliberately as a means of planned social influence. To influence norms, a model person can show desired behaviour directly in everyday life, on television, posters, or in other media. Both real and fictitious persons or even animals (in comics and cartoons) can serve as models. The higher the status and charisma a person has - in the subjective experience of the model learner - the more likely it is that the model behaviour will be performed by the learner. A large number of models has a stronger effect than a small one. What models have the greatest impact depends on the target group. The target group determines who has high status and charisma, who is trustworthy and thus norm-defining (Wagstaff and Wilson, 1988; Winett et al., 1982; Winett et al., 1985). Example: Famous athletes who travel by train or bus instead of by car or plane whenever possible.

Giving feedback and enabling self-feedback: Giving target persons, groups, or organisations feedback about their individual or collective behaviour and/or its environmental impact can change their future behaviour. The more individual the feedback is and the more immediately it follows the behaviour, the more effective it is. This instrument can only work by referring to norms that are already internalised by the target groups. If the members of a household are informed about their consumption of electricity or water during a certain period of time and about the cost, their consumption may change. The success of this instrument depends on a fast, regular, specific, and trustworthy feedback (Midden et al., 1983; Pallak and Cummings, 1976; Pallak et al., 1980; Rothstein, 1980; Mosler and Gutscher, 1998).

Feedback is not just a way of confronting a person with contradictions between goals and behaviour (compare section 3.5.2.), but it helps the actor to keep the goal in sight and to be able to react quickly to discrepancies between goals and reality. Feedback information is also efficacy information about individual or collective behaviour. Self-feedback is based on a person's own behaviour records, such as diaries about daily travel behaviour (times and places of start, destinations, distances, and times of arrival). Examples: Fuel consumption display in the car; energy consumption account for a certain time period; driver's logbook; " $\mathrm{CO}_{2}$ calculator", a model for determining personal $\mathrm{CO}_{2}$ emission and energy consumption. ${ }^{12}$

\footnotetext{
11 Note that model learning is a broader term than Bandura's (1986) notion of observational learning, which does not include language-bound learning about behaviour experiences of others.

12 An example can be found online in the WWW at <http://CLEAR.eawag.ch/models/index.html>.
} 


\subsubsection{Communication instruments with direct request}

Persuasion is the attempt to influence another person's beliefs about factual reality, possible reality, and options for action, and about appraisals, goals, and norms. In addition to presenting certain contents, the communicator accompanies the presentation with the more or less overt demand to adopt the presented contents.

In the case of persuading about facts, the communicator attempts to persuade somebody of the truth of certain facts. Persuasion is used when target persons are not automatically willing to believe the presented facts. For instance, a minority of scientists tries to persuade people that human release of carbon dioxide is not a relevant cause of global warming.

When persuading someone about options, the communicator tries to present a possibility not only as a theoretically imaginable reality, but also as a realistic option. The objective is to either show that a certain desirable possibility can be achieved realistically, or to persuade the target person that we risk a specific undesirable development or outcome becoming reality. This implies that persuasion about desired or undesired possibilities has to be combined with the pointing out of behaviour options that can promote or prevent these possibilities.

To persuade people that something is the case or might be the case is one thing. To persuade people about what ought to be the case - i.e., persuading about goals, appraisals and norms is another thing. If people have learned that releasing greenhouse gases leads to global warming, they also have to be persuaded that global warming is hazardous, and that one has to take measures to reduce greenhouse gas emission. Since goals affect appraisals, persuading people successfully about goals will have an effect upon their appraisals. On the other hand, communicators can also try to persuade people about appraisals. They can try to persuade people that something has to be appraised in a certain way, that something is good or bad, right or wrong, important or irrelevant.

In persuading about facts, possibilities, goals, or appraisals, the success chances of a communicator depend - among other things - on his or her trustworthiness. The communicator can, but need not, be a famous person. Neighbours and other familiar persons can also be persuaders. Success depends also on direct personal contact, which is much more effective than written persuasion attempts. Communicators can be trained to use vivid language, to use information that is relevant for the addressee, and to involve him into the conversation (Burn, 1991; Burn and Oskamp, 1986; Gonzales et al., 1988; Hopper and Nielsen, 1991). Persuasion is only possible if the arguments used are compatible with at least some of the values that the target person already has. Examples: Information exchange within GAP groups (see the chapters by BRUPPACHER AND ULLI-BEER and by VATTER ET AL.); television commercials; "ambassadors" in the 30-kilometers-per-hour campaign in Münsingen (see the chapter by GUTSCHER ET AL.).

In order to persuade people of the need to change goals it may be helpful to confront them with contradictions between a goal they pursue and their behaviour. Such discrepancies are experienced as unpleasant, so that people are motivated to resolve them through either a change in attitude or a change in behaviour (Kantola et. al., 1984). However, it is important not to build up too much pressure and to leave enough face-saving opportunities. Otherwise target persons are likely to react by 
rationalising and playing down the conflict, so that the desired behaviour change does not occur. Examples: Persuasion about the fact that road traffic is still increasing; persuasion about the option to replace a considerable share of road traffic by rail transport or to avoid it by new modes of organising work (e.g., telecommuting); persuasion about the appraisal that a further increase of road traffic is undesirable and about the goal that it should be avoided by specific means, such as higher fuel prices and better rail infrastructure.

Sending appeals: An appeal is a general request to behave in a certain way. In contrast to "prompts", these messages are not delivered at the very place of action. Appeals can be expressed with or without arguments. Sending an appeal to do or not to do something is actually the same as persuading somebody about a behaviour related goal. Examples: Summer smog poster campaign in Bern in 1996: "Drive at low engine revolutions or leave your car at home".

\section{Example 11: \\ Stimulating self-commitment as a means against traffic jams}

In this study the task was to reduce, during a special action week, morning and evening traffic congestion that regularly formed at the Baregg highway tunnel near Zurich. Traffic back-ups result from local and temporal overuse of the common pool resource "traffic space". By means of a publicity campaign and public collection of signed statements of selfcommitment from a core group of about 18,000 regular commuters it was attempted to establish a kind of rotation system in avoiding travel at peak traffic times. The main intervention instrument consisted of public self-commitments, in writing, that were available through newspaper advertisements and the Internet. To support diffusion and as a reminder during the experimental week, drivers were also encouraged to display their participation in the form of bumper stickers on their vehicles.Compared to the baseline week, the total reduction of traffic congestion amounted to $10 \%$ or two hours respectively. Per peak hour in the morning, 100 cars travelled at other, less busy times. The study demonstrated that the contributions in the form of signed self-commitments were in fact effective and that the statistical levelling regular distribution of the uncoordinated contributions to reduce traffic during the periods of heavy traffic - functioned reliably. The publicity and public acceptance of the principles of this campaign based on voluntary contributions were very large in scale (Gutscher et al., 2000).

Presenting prompts and reminders: Prompts and reminders tell target persons what behaviour they are expected to show. The medium for these messages can be signs, stickers, posters, flyers, brochures, oral speech, and so on. It is important that the messages are placed where the behaviour takes place or is supposed to take place (Aronson and O'Leary, 1983; Baltes and Haywood, 1976; Hopper and Nielsen, 1991). These instruments activate norms that already exist in the target individuals. They are reminders about commitments or earlier intentions. Examples: "Turn the motor off at red lights", "Turn the computer screen off before your coffee break".

Stimulating self-commitment: Self-commitment means that people oblige themselves to behave in a certain way. It is expected to make an individual's environmental goals conscious and 
thus behaviour-guiding. Self-commitment is probably one of the most efficient instruments with regard to fostering a desired behaviour (Bachmann and Katzev, 1982; Pardini and Katzev, 19831984; Wang and Katzev, 1990). Commitments can be practised publicly or privately. Public selfcommitment involves communicating the commitment made to the public, such as by means of an advertisement or a sticker. Example: The director of a company commits himself to travel to work by public transportation for a month and publishes this in the company magazine (at the same time, this is an example of model behaviour); public commitment of a large retail trade company that $75 \%$ of the transports from distribution centres to the shops will take place by train (see Example $11)$.

\subsubsection{Diffusion instruments}

The diffusion instruments described here are used primarily for the first step of initial diffusion (see section 2.5. above and the chapter by FLURY-KLEUBLER AND GUTSCHER). We order diffusion instruments according to whether diffusion takes place in direct personal encounters, via person-toperson media, or via the mass media.

Diffusion instruments are in fact the "shipping containers" to transport communication instruments, or their mechanisms. As a rule, they require a "transmitter", or communicator. These are usually real persons, or where diffusion occurs in written form, organisations or institutions. The actors responsible for the intervention are not always the transmitters or communicators. The responsible parties may employ the help of transmitting communicators or so-called "multipliers".

Multipliers can be recruited to use their social contacts or social status to support the goals of a planned intervention. No matter how contact is established - direct personal contact through person-to-person media or contact through mass media - multipliers bring communication instruments into effect with single individuals or several persons at a time by means of monologues or dialogues or through offering directly observable model behaviour. (Multipliers may, for example, talk directly with acquaintances, others at work, fellow club members, or they may give interviews in a local newspaper.)

The effectiveness of multipliers can be increased if they receive training or some kind of information support. If there is a need to systematically contact large numbers of strangers, multipliers generally receive training and are paid for their work. For multipliers working in this manner, the term activators has also been used in the literature (Gonzales et al., 1988). The efforts of multipliers can also take on the form of low-threshold advice, whereby the driving force of the diffusion of new behaviours takes place through active consulting (examples: energy use advice, advice on composting ).

Direct personal diffusion and diffusion based upon person-to-person media make use of the personal relationship of the transmitter, or communicator, to the receiver, or recipient. It is important to take advantage of existing contacts within the multiplier's social network, so that recipients are contacted by familiar communicators. Familiarity also plays a role when communicators appear 
in the mass media; people are receptive to messages from well-known and well-respected communicators, and in this way, target groups are reached more easily and efficiently.

Establishing direct personal contact: In the case of non-media communication, diffusion typically occurs face to face. In this setting monologues play a part in the form of announcements, lectures, speeches, or theatre pieces. Forms of dialogue may include anything from a conversation between two persons to group discussions or discussions with moderators - among other things, for example, in the framework of participatory planning processes or various forms of initiating public discourse (for example, Round Tables, Public Discussion Fora, or Local Agenda 21 Processes.) Social changes can not simply be "put through". Social change has to go down the tedious and risk-laden path of democratic, participatory, and argumentative procedures. "Solutions" to environmental problems require adaptations and modifications that people understand, accept, and carry out. This is the reason why it is absolutely essential that people from all walks of life, through extensive dialogue, reach a common determination of the goals and contents (see Example 12).

Besides face to face settings in a narrow sense, there is another type of non-media diffusion, whereby organised models carry out certain model actions publicly (highly visibly to others).

A further special form that is based for the most part on non-media diffusion are so-called diffusion tasks (Prose and Wortmann 1992; Prose et al., 1994; Mosler and Gutscher, 1998 and Mosler and Gutscher, in prep.). Here a number of target persons, usually simultaneously, are asked or instructed to pass along a certain object to friends and acquaintances. The object passed along may be, for example, a brochure that presents facts, interpretations, and an appeal. Diffusion as a rule then takes place as a chain reaction; if the instructions include photocopying the object, the spreading may take the shape of an avalanche.

The initiation, building, and management of networks are also based mainly on non-media contacts, or sometimes on contacts via person-to-person media. Here there is the additional goal that individuals or corporate actors in a chain or network introduce themselves and get to know each other. In this way, a virtual collective is formed, which facilitates the exchange of information and experience (see the chapter by B ÄTTIG AND BALTHASAR on network management within the Swiss federal government's Energy 2000 Action Programme). Networks can also support the building of special consulting and continuing education offerings that individual members could not afford to pay for on their own. Networks can have further synergy effects, such as in shared financing of demonstration projects, the development of employee training programmes, public campaigns, and so on. Similarly, networks can combine the political efforts of their members and thus increase their effectiveness.

Establishing contact via person-to-person media: Diffusion can also be designed using person-to-person media; most important are letters, telephone conversations, faxes, or e-mail. We are already seeing newer forms of person-to-person media today, such as the popular Short Message Service on mobile phones. Many other new possibilities for audio-visual media communication will be available in the near future. Common to them all is the fact that they are used generally by individuals to communicate with other individuals. The transition to mass media is fluid, how- 
ever; fax, letter, and e-mail can also be used to contact a large number of people. In principle, person-to-person media are suited to facilitating a range of forms of communication, from both monologues and dialogues to moderated or non-moderated discussion forums or mail groups.

Establishing contact via mass media: The World Wide Web offers innumerable variants of contacting target groups. Its technologies also allow for relative spontaneous, more personal forms of dialogue, through e-mail, for example. The possibility to implement communication instruments via the Web are virtually unlimited: NGOs, environmental agencies, universities, research groups, and private persons present a large body of facts, options, appraisals, model behaviours, and action possibilities as well as various forms of persuasion and appeals. However, as the Internet does not as a rule represent a push technology, as a first step diffusion of the offerings is needed, either through Web portals or via conventional mass media.

\section{Example 12: \\ Paragliders and wildlife}

$P$ aragliding has become very popular since the late 1980s (in Switzerland, 10,000 pilots were trained in a five-year period). Ethological research has shown that in some areas, wild animals, especially ibex, do not adapt to the paragliders: they flee every time a paraglider flies overhead, and they end up spending their days in wooded areas at lower elevations. Here they do not find appropriate fodder and instead start to eat young trees. Also, observations show that paragliders disturb some rare eagle species during breeding periods (see Ingold, 1999).

Alarmed by these findings, the national wildlife protection agency set up a national task force for in-depth investigation of the problem. At the local level, the authorities started a participatory problem-solving procedure involving all relevant local actor groups.
This group made a careful analysis of the local problem situation, bringing in not only the point of view of the wildlife specialists, but also the perspectives of the paragliders, farmers, tourist managers, and others. This led to solutions that were adapted to the specific local context and acceptable to both wildlife protectionists and paragliders. Agreements were made on certain rules that paragliders will observe on a voluntary basis (e.g., to avoid flying over specific areas during certain periods). Control is exercised by the local authorities, and as long as the rules are observed, they will forego decreeing legal regulations (for details on the procedure and its effects see Ingold, 1999).

Television or radio shows, newspapers, and books are conventional mass media that serve well as vehicles of communication instruments. They include editorial reports that base on research or on media conferences, but also paid advertising in the form of commercials or other ads. Printed products comprise brochures, flyers, and the like; they continue to carry the heaviest load in traditional information communications. Examples: Leaflet for people who have moved to a new town and who do not yet know what to do with different kinds of trash, such as recyclable glass, paper, or used batteries. 
There are various technical possibilities for distributing printed products: they can be distributed by people (common for flyers and newspapers) or by mail, or be available in dispensers. Dispensers refer to all possible physical arrangements that serve to offer, or distribute, communication instruments that base mainly upon printed products.

Diffusion by means of films at cinemas or other image and sound recordings represent another type of mass media diffusion. The poster is a prototype of an information carrier that uses pictures and language in all sorts of designs. Dispensers, in addition to facilitating distribution, can also take on mass media functions. Through their design, they can attract attention and present appeals. This makes dispensers themselves vehicles of communication instruments, and they fulfil the same tasks as the poster.

Various goods produced by people, whether through mass or unique production, are also possible vehicles of communication instruments. At present, this potential is still being utilised mainly for image advertising and for firmly establishing brand names.

There is another aspect of contacting that plays a role in diffusion via the mass media: the $d e$ gree of specificity of addressing. Contact can be established personally (through personally addressed direct mailings, for example) or impersonally (anonymous mailings, television and radio shows, printed materials, and so on). Here the issue is the extent to which people feel that the communication is personally addressed to them and that they are obligated to give the matter attention. Certainly, personal address is preferable, such as when all residents of a town receive a letter. If contacting is impersonal, a certain degree of control in reaching a target group is possible through positioning the message at sites and places assigned to particular persons (mailboxes, for example) or through the use of target-group specific media channels. If this is not possible, it is up to individuals in the target group themselves to attend to the message (self-selection). In such cases, efforts are made to tailor-design the communication instruments to appeal to a specific target group. Gaining the attention of a target group is thus an issue for diffusion instruments (certain diffusion instruments attract more attention than others) and also a question of the design of communication instruments.

\subsubsection{General remarks on the application of communication and diffusion instruments}

The various diffusion strategies have advantages and disadvantages: Diffusion via direct personal contact or person-to-person media requires enormous efforts, but it guarantees targeted access to difficult to reach persons or corporate actors. Diffusion via the mass media suffers the most from the problem of loss of spread.

In the work of diffusion, therefore, it seems generally advantageous to use the most familiar persons as possible as communicators and to address the target group in the most specific and personal way possible. The scope of the present discussion does not allow us to go into the details of further dimensions of communicators, such as expert status, competency, charisma, credibility, trustworthiness, engagement, similarity, physical attractiveness, and sociometric status (O'Keefe, 1990). 
Table 2 shows the basics that are required of diffusion and communication instruments (compare the chapter by FLURY-KLEUBLER AND GUTSCHER; Kok and Siero, 1985; Zimbardo and Leippe, 1991: 137). In a first step, diffusion instruments guarantee efficient and rapid "transmission" of the intervention to the individuals in the target group and secure their initial attention. Widespread norms of interaction, or politeness, guarantee that diffusion through personal contact, or through person-to-person media, will gain at least a minimum of initial attention. The continued success of diffusion depends upon the design of the communication instruments. Design involves formulating the topic and/or "packaging" the topic in a way that attention is sustained. The content of the communications must be understandable; that is, it must be adapted to knowledge and language of the target group. In order to reach the necessary level of acceptance of the content and conclusions, communications have to base upon the target group's existing structure of values and norms. Content and consequences also have to be able to become anchored in memory as well as influence the forming of intentions. Finally, and most important, intentions have to be expressed in actual new and changed behaviours, whereby stabilisation of a new behaviour will place additional requirements on communication instruments.

Table 2: Requirements of diffusion and communication instruments.

\begin{tabular}{|ll|}
\hline Type of instrument & Required \\
\hline Diffusion instruments & Exposure and initial attention: \\
& The instrument must gain the attention of all individuals \\
in the target group and thus expose them to the effects \\
of the communication instrument. \\
Attention: \\
The instrument must direct target persons' attention to \\
its content and goals. \\
Comprehension: \\
The content and goals communicated by the instrument \\
have to be understandable. \\
Acceptance: \\
The content and goals communicated have to be able \\
to be accepted, that is, receive a positive evaluation. \\
Retention: \\
The new content and goals must become anchored in \\
memory. \\
Intention: \\
The new content and goals should lead to the forming \\
of intentions. \\
Behaviour: \\
The new goals should be expressed in behaviour in a \\
successful and lasting way. \\
\end{tabular}


The requirements can not always be fulfilled through a single combination of a communication instrument and a diffusion instrument. As a rule, a mixture of different, complementary combinations - in temporal succession - is implemented. In designing the communication instruments it is very important to have knowledge of the values, norms, knowledge, and acceptance conditions of particular contents in various segments of the population (compare the chapter by VATTER ET AL.). Moreover, it is necessary to be aware of the contents and main thrust of communications that are currently being communicated by other sources. When using communication instruments, we have to reckon with the fact that a large number of other actors are using such instruments as well. The effects of all these attempts at social influence interact with each other. So it is not unlikely that a sole caller in the desert remains unheard.

In order to maximise the probability that particular segments of the population will be exposed to the effects of a certain intervention, costly combinations or repeated strategies may be required. In order to select a diffusion instrument and design it in concrete form, it is therefore important to have information about the best way to reach particular target groups. Where this information is lacking, it should be generated by preparatory studies, such as surveys or other means of collecting data. Only then can decisions be made on whether differing, target group specific variants of the communication instruments should be implemented; whether in the framework of certain strategy goals it is sufficient to address only a particular segment of the population; or whether blanket, non-selective diffusion of a single communication instrument will suffice.

\section{Comparison and preliminary evaluation of the instrument types}

As stated above, the typology of instruments that we present should help us to look at classic policy instruments as well as new instruments from an actor-oriented perspective, and it should allow instruments to be evaluated with respect to issues of practical interest (effectiveness, costs, and acceptance). We will now try to make a preliminary comparison and evaluation of the instrument types with these goals in mind.

Looking at policy instruments from an actor-oriented perspective means that one has to refer to a general conceptual framework or model of human action. Such a conceptual framework was outlined in the Introduction chapter by KAUFMANN-HAYOZ AND GUTSCHER (see Figure 1, page 23). The primary targets of the different types of instruments can be explained according to this conceptual framework. In Figure 1 below we have visualised them by adding the instrument types to the model of human action. Of course, only the primary points of attack are shown in the figure. Obviously, if an instrument achieves primary changes in internal or external structures, this may have a number of secondary effects, since the actors respond and adapt to these changes. 


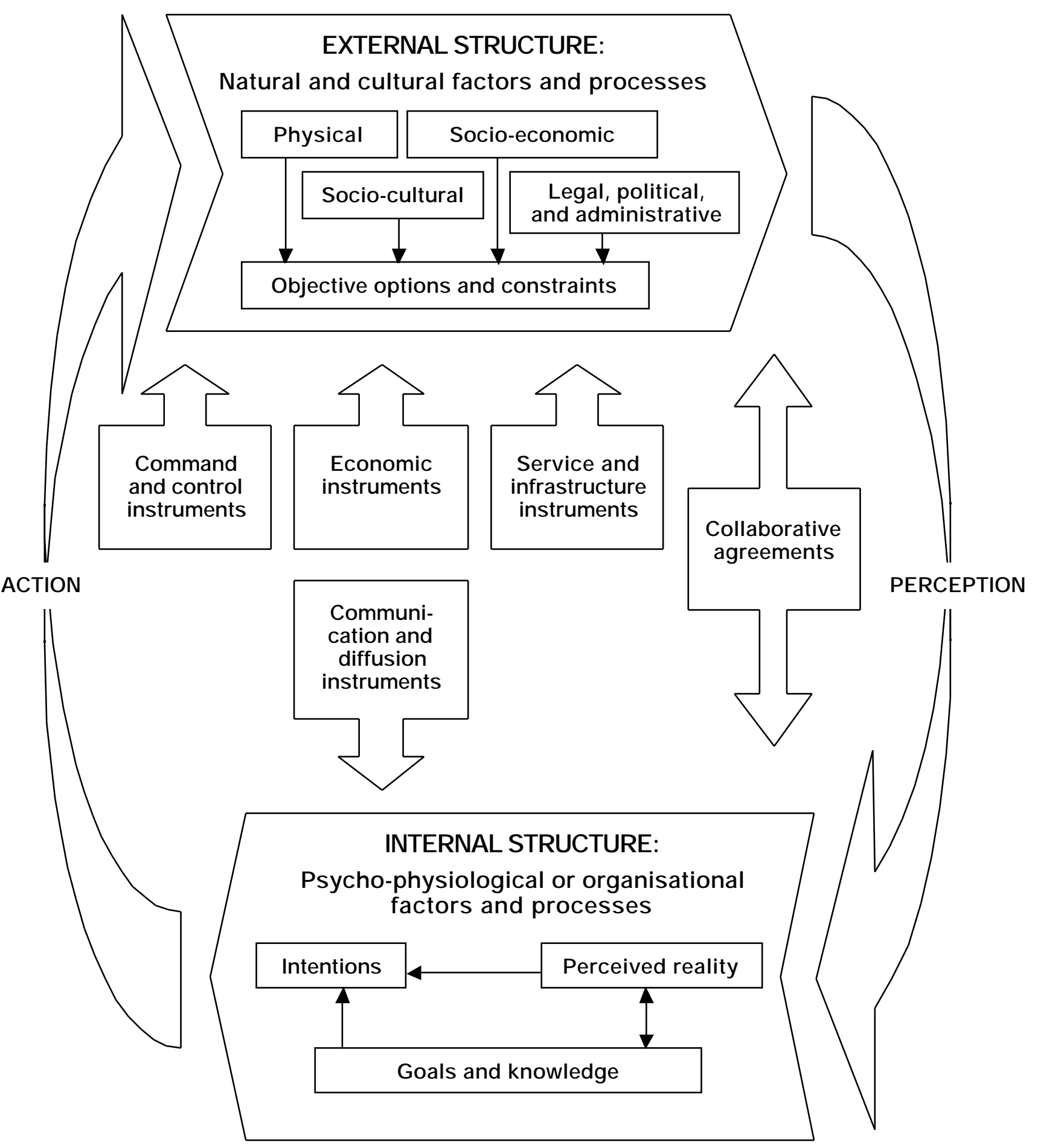

Figure 1: Primary targets of the different types of instruments. 
Does an instrument aim primarily at modifying the individual or organisational actors' internal structures (their goals and their decisions about how to achieve these goals), or does it target the external structure (the physical, cultural, socio-economic, and political, legal, and administrative framework of action)? The first three types - command and control instruments, economic instruments, and service and infrastructure instruments - clearly aim primarily at modifying different aspects of the external structure: the political, legal, and administrative, the socio-economic, and the physical environment. Most command-and-control instruments as well as many service and infrastructure instruments directly restrict agents' options, while economic instruments and some service and infrastructure instruments make environmentally desirable actions more attractive or rewarding and undesirable actions less attractive. In contrast, most communication and diffusion instruments clearly aim at influencing the actors' internal structures. They attempt to influence the knowledge and goals of individuals and organisations and their respective ways of achieving them as well as to affect their perceptions and appraisals of the social and physical reality. The design or re-design of institutions is initially based on the interaction of individual and organisational actors, and communication and diffusion instruments predominate. However, every one of the instruments can in principle support the concrete, blanket administration of institutional arrangements. Some types of collaborative agreements aim at influencing the goals and norms that companies set for themselves and can therefore be regarded as influencing the internal structure of companies. Others influence primarily the economic and legal-administrative framework of action and the relations between companies and other actors (especially public authorities and NGOs).

We will now try to discover further differences and similarities among the five types of instruments by answering the following seven questions. Table 3 (page 90f.) summarises the questions and the main elements of the answers.

- Why is the instrument effective?

- Who can apply it in the main?

- What are the most important target groups?

- What can be said about its effectiveness?

- What innovations does it promote?

- How well is it accepted?

- What effort and costs does it involve?

\subsection{Why is the instrument effective?}

The assumptions and hypotheses about the actors' responses to the introduction of an instrument constitute its rationale. This explains the mechanisms according to which an instrument is supposed to work, i.e., to have an effect on the target group's goals and their ways of achieving them. The basic rationales of the different types of instruments were described above (sections 2.1 through 2.5), and they are summarised in the first line of Table 3. It can be seen that the different 
types of instruments are supposed to influence the actors' behaviour for different reasons. While command and control instruments are believed to have an effect because people want to avoid the penalties associated with the violation of the prescriptions, economic instruments are supposed to steer behaviour because the actors make decisions according to economic rationality. Service and infrastructure instruments have an effect by making certain behaviours possible, salient, or attractive, and they exclude others or make them unattractive. Collaborative agreements work by generating - through negotiations - a more or less binding commitment of (collective) actors to behave in a certain way. Finally, communication instruments influence people's values and knowledge, which are assumed to be important determinants of intentions and the choice of goals.

\subsection{Who can apply it in the main?}

Public authorities can implement all instruments, whereas private actors can apply only some of them. In Western democracies, only legislative authorities are legitimised to use command and control instruments, and only they can create the legal basis necessary for most economic instruments and for many important infrastructure instruments.

\subsection{What are the main target groups?}

With respect to the target groups, there are no clear distinctions among the five types of instruments. All of them - except collaborative agreements - may be directed to collective actors, especially companies, as well as to individuals or unorganised target groups. In collaborative agreements, the companies or associations involved are at the same time actors and target groups. The distinction between the actors who apply the instrument and the target group disappears. The same applies to some communication and diffusion instruments: In a participatory planning process, for example, the public authority may be the actor who initiates the process, but at the same time it is also part of the target group.

\subsection{What can be said about its effectiveness?}

In the literature on policy evaluation, a distinction is often made between impact and outcome. When evaluating the impact, we ask whether or not the application of an instrument has the intended effects on the behaviour of the target group. When evaluating the outcome, we examine all direct and indirect, intended and unintended effects as a result of or in addition to the consequences of the target group's behaviour change. In the case of environmental policy, the effects on the environment are of course among the most important outcomes. Two essential aspects of evaluation 
are, therefore, (a) the scale according to which the effects are measured, and (b) how large the target group is that has been impacted by the measure. An electricity saving campaign in an office building may, for instance, have a strong impact, because all employees change their habits and switch off computers and light bulbs whenever they are not in use. As an outcome, the electricity consumed by these appliances in this particular building may be reduced by $30 \%$. However, this may be only a fraction of the building's total electricity consumption, and only one out of 1,000 companies may run such a campaign, hence the ecological outcome of the instrument on a national scale, for example, will be judged quite small. In the following, we make some rough, preliminary comments on what is known about the effects of the different types of instruments.

\subsubsection{Command and control instruments}

Environmental policy in Switzerland and elsewhere is still essentially based on command and control instruments, and the positive effects are acknowledged (see, e.g., Jänicke and Weidner, 1995). A main advantage is that their effectiveness is highly foreseeable. Economists like Vallender (1990) or Kirchgässner (1997) emphasise that these instruments are successful under certain conditions: "Successes are achieved where standards or prohibitions can easily be implemented and where they are effective for regionally limited problems" (Kirchgässner, 1997: 185). Nonetheless, there is a general consensus that traditional environmental policy has somewhat reached its limits (Kirchgässner, 1997: 187). The main drawback of command and control instruments from an economic standpoint is their rigidity, which may hinder the efficiency and effectiveness of environmental policies.

Basically, command and control instruments make the same prescription for every member of the target group. Taking the example of emission standards for industries, every company has to limit the emission to the same level, regardless of the individual cost. It would be more efficient, however, if companies with lower expenses for reducing emissions would observe lower emission levels, whereas firms with higher costs would be allowed to pollute more. Moreover, under a regulatory regime, companies that already comply with the emission standards do not have any incentive to invest in further improvements. Theoretically, command and control instruments could be tailored according to the conditions of different target groups. However, this approach is exposed to the lobbying of powerful interest groups and demands a lot of resources and technical expertise within the public administration (Kirchgässner, 1997). In domains with rapid technological change, such instruments are not recommended, whereas prescriptions of a technologically up-to-date standard can stimulate the diffusion of an innovation and have significant secondary economic benefits (Balthasar and Knöpfel, 1994).

Command and control instruments apply - in theory - uniformly to everybody, independently of individual economic strength. But this does not imply that everyone is affected alike; command and control instruments are not a priori compatible with social objectives. They can, however, support or encourage the application of other types of instruments. Existing legal norms can accelerate the development of economic instruments, of collaborative agreements, of service and infrastruc- 
ture, and of communication instruments. For example, the decision for a ten-year nuclear moratorium in Switzerland has fostered an expansion of the federal energy action programme Energy 2000.

\subsubsection{Economic instruments}

The impacts of economic instruments on the behaviour of target groups can be assessed for various time ranges. If, for example, a tax on non-renewable energy is introduced, a short-term effect may be that the existing infrastructure is used less extensively and that energy waste is being avoided. In the medium term, investments in more energy efficient infrastructure or in appliances powered by renewable energy will be made. In the long term, research and development of such alternative techniques and appliances is stimulated. When considering the possible introduction of economic instruments (such as a tax on carbon dioxide), many countries have used modelling and forecasting techniques to investigate their likely costs and benefits. But even if the number or practical applications of economic instruments is growing, there is still very little systematic evidence about the performance of such instruments in practice. This is due first of all to the fact that experiences are too recent, and some of the effects take quite a long time to become evident. Thus there is little empirical evidence about the impact on technological change. Second, suitable data on emission sources is often lacking. Finally, there is an important conceptual difficulty in evaluation: the need to define the alternative (What would have happened without this instrument?). Despite these uncertainties, economic instruments now enjoy the reputation of "proven successes in reducing pollution at low cost" (Stavins, 2000) and they have moved into the centre of political debate. This debate is quite different from the controversy in earlier times, when these concepts were considered to be "licenses to pollute". In 1997 the OECD concluded that "greater efforts to evaluate the efficiency and effectiveness of economic instruments actual in practice would contribute greatly to improve future policy" (OECD, 1997b: 132).

\subsubsection{Service and infrastructure instruments}

In general, if environmentally sound action is unpleasant or even risky due to infrastructure and service conditions, only idealists and people who can not afford the more pleasant alternatives choose the environmentally preferable alternative. In a country or area with poor public transportation, only persons who do not have access to a car will use it. If environmentally sound food is only available in a few small shops far away from where the people do their everyday shopping, only few people will buy it (and those who do may have to drive their private cars to get it...).

The connection between infrastructures and services that enable or encourage environmentally undesirable behaviours and the frequency of these behaviours is obvious from past developments. Consider the following examples: Water consumption per capita rose at least ten times after the installation of running water in houses and flats, particularly after the introduction of the flush toilet. Traffic volume usually grows with the increasing supply and quality of roads. Shopping centres and leisure facilities at the periphery of cities attract motor traffic, and the availability of park- 
ing spaces at the destination is one of the major determinants of the choice to use a private vehicle. On the other hand, an attractive and safe net of bike trails in cities encourages the use of bicycles as a means of transportation. It has also been shown that the design of roads influences the driving style of car drivers: If a road affords slow and steady driving instead of a stop-and-go pattern, traffic becomes more fluent, and emissions are significantly reduced (see, for example, Haefeli et al., 2000). Finally, the demand for organically grown food in Switzerland has increased considerably since the big grocery stores started to offer it along with their "traditional" vegetable supply. The effectiveness of many infrastructure and service instruments, especially of attraction based forms, depends on whether demand can be created. Also, infrastructure instruments that are physically built structures and facilities often have very long-term effects, and they are hardly reversible within a few years or decades.

\subsubsection{Collaborative agreements}

An advantage of collaborative agreements is that they allow environmental targets to be reached without unnecessarily restricting entrepreneurial freedom of action and without unnecessary additional cost. Generally, agreements can only have higher conformity with the goals than command and control instruments if government and industry have identical interests, if an already ongoing development and modernisation process is accelerated or supported, and if the industry can achieve the targets without economic disadvantages and without distortions in competitiveness (Rennings et al., 1997). However, the incentive to enter into agreements can be diminished once the target is achieved, if no further targets are set (Kohlhaas and Praetorius, 1994). As Kirchgässner puts it:

"[Voluntary agreements] are actually a substitute for command and control policies and not for market oriented measures. Such agreements are rather popular with producers, as they are able to use their information advantage in the bargaining process with the public bureaucracy. They may be of some use as they can - compared with one-sided bureaucratic measures - lead to lower (economic) costs of environmental policy, possibly at the cost of lower standards and, therefore, lower environmental protection. More important is, however, that they share the basic weakness of bureaucratic measures: because prices below a certain emission limit are zero, there is no incentive to further reduce emissions below these limits and to develop new techniques with lower emissions. Moreover, as the literature about rent-seeking tells us, given such possibilities there are strong incentives to invest in political bargaining instead of emission reduction”(Kirchgässner, 1997: 187).

A considerable disadvantage of agreements is their legal non-commitment and their non-suability, when, for instance, the economic situation does not allow participants to continue to pursue the set targets. The reason for this is that the binding factor of agreements is only of a political, but not of a legal nature. Experience indicates that the binding effect is actually stronger if the number of actors involved is smaller and if communication among the parties is intensive. However, the reali- 
sation of environmental goals through collaborative agreements still lags behind realisation by command and control instruments (Rennings et al., 1997).

\subsubsection{Communication and diffusion instruments}

The impacts of communication and diffusion instruments used within action campaigns to influence the behaviour of specific target groups are well documented in many cases (see, for example, Dwyer et al., 1993; Gardner and Stern, 1996; Hopper and Nielsen, 1991). However, the effects are sometimes small or questionable in terms of environmental outcomes. This has to do with the fact that the potential influence of behaviour change on resource consumption and environmental pollution is often very limited. For instance, household energy consumption is determined to a large extent by the physical characteristics of a building and by the technology for regulating room temperatures. "Energy saving behaviour" of residents, even if exemplary, has only a small influence on the overall energy consumption of the household (Ligteringen, 1999). Also, interventions of this type often reach only a small segment of the population. For this reason, efforts to move the broader public to use, for example, infrastructures in a more conscious and energy-saving manner are frequently seen to be an inefficient alternative (compare here, for example, Stern 2000b: 410). But the fact should not be overlooked that such campaigns are useful in creating the motivational groundwork preparatory to promoting the rapid spread of new, more efficient technologies through other types of instruments (compare the chapter by MAUCHET AL.).

However, communication and diffusion instruments are not confined to short term campaigns. In a larger view, communication is also a matter of building up a comprehensive and high quality educational system that is available to the entire population. And it is a matter of a responsible media policy that does not leave everything to market forces. Last but not least, it is a matter of promoting problem-oriented research activities. In addition, communication and diffusion instruments may play an important role in mitigating some of the drawbacks of classic policy instruments. The neglect of psychosocial and behavioural aspects accounts for a number of the difficulties encountered with the policy instruments described above: (1) Command and control instruments are often perceived as constraining personal freedom and autonomy; they may therefore cause the behavioural phenomenon of reactance. In addition, the enforcement of legal prescriptions directed towards barely accessible target groups is often very difficult, because control is almost impossible. Therefore, the motive to avoid sanctions disappears. (2) Economic instruments - besides the problem of acceptance, especially among the industry - can lead individuals to act illegally in order to avoid paying fees (illegal waste disposal may have this motive), and they may destroy intrinsic motivations to act environmentally responsibly ("I pay for having my trash collected, therefore I can legitimately produce as much trash as I want"). (3) Collaborative agreements, such as ISO 14001 certification, require implementation within the enterprise down to the level of the daily routines and decisions of individual employees. Thus, communication and diffusion instruments may be very helpful in participatory policy development, in accompanying the implementation of collaborative agreements or economic instruments, and in enforcing command and control instruments. 


\subsection{What innovations does it promote?}

A special and very important outcome aspect of policy instruments is their potential to promote innovations. We can examine this potential of the various types of instruments and find out what kind of innovations it promotes. Command and control instruments apparently have the potential to promote the diffusion of the best available technology at a given time, but their potential to promote continuous improvement seems to be limited. In contrast, a major advantage of economic instruments is seen in their very potential to stimulate continuous technical and organisational improvements in order to achieve environmental targets as efficiently as possible. They provide an incentive to reduce all units of pollution rather than to simply comply with the legal requirements. Service and infrastructure instruments are often themselves social and institutional innovations. Collaborative agreements may not only stimulate technical and organisational innovations, but they may also lead to new institutional arrangements (for instance, for the control of certifications and labels). Finally, communication and diffusion instruments promote the diffusion of available new technologies, and they play a decisive role in the initiation of new institutional arrangements. To the area of communication and diffusion instruments fall the transmission and evaluation of new knowledge and the consequently derived judgements and setting of goals that will shape the design of new resource regimes.

\subsection{How well accepted is it?}

In a democracy, the implementation of classic policy instruments depends upon public acceptance. Therefore, the question of the acceptance of an instrument type is of practical importance.

\subsubsection{Command and control instruments}

As the main elements of traditional environmental policy, command and control instruments are still quite accepted, although there is a growing resistance against the increasing density of regulations, because they restrict entrepreneurial freedom and entail complicated bureaucratic control mechanisms.

\subsubsection{Economic instruments}

Economic instruments have been propagated by economists for decades (Pigou, 1952). Although usually believed to be effective, they are often not well accepted. Opponents are afraid that they will weaken a nation's industry's position in international competition - especially if economic instruments are to be implemented in a single-handed effort of one nation alone.

In contrast, those in favour of the instruments argue that early implementation of economic instruments forces a nation to make the necessary investments and to stimulate technical progress. 
Table 3: Summary of the main features of the different types of policy instruments.

\begin{tabular}{|c|c|c|}
\hline & $\begin{array}{l}\text { COMMAND AND CONTROL } \\
\text { INSTRUMENTS }\end{array}$ & ECONOMIC INSTRUMENTS \\
\hline $\begin{array}{l}\text { Why is the instru- } \\
\text { ment effective? }\end{array}$ & $\begin{array}{l}\text {...because people want to avoid the } \\
\text { penalties for non-compliance. }\end{array}$ & $\begin{array}{l}\text {...because people want to achieve } \\
\text { maximal benefit at minimal cost. }\end{array}$ \\
\hline $\begin{array}{l}\text { Who can apply it in } \\
\text { the main? }\end{array}$ & - Public authorities & - Public authorities ${ }^{1}$ \\
\hline $\begin{array}{l}\text { What are the most } \\
\text { important target } \\
\text { groups? }\end{array}$ & $\begin{array}{l}\text { - Individuals } \\
\text { - Companies } \\
\text { - Public and private organisations }\end{array}$ & $\begin{array}{l}\text { - Companies } \\
\text { - Individuals }\end{array}$ \\
\hline $\begin{array}{l}\text { What can be said } \\
\text { about its effective- } \\
\text { ness? }\end{array}$ & $\begin{array}{l}\text { - Effectiveness highly foreseeable } \\
\text { - Effective if compliance easily } \\
\text { controlled } \\
\text { - Relatively inflexible - not very } \\
\text { adaptable to specific situations } \\
\text { - Can adapt to changes only slowly }\end{array}$ & $\begin{array}{l}\text { - Reaches goals at minimal cost } \\
\text { - In practice often limited } \\
\text { effectiveness due to low taxes, } \\
\text { undifferentiated charges, and ap- } \\
\text { proval of exemptions } \\
\text { - Provides incentives for improve- } \\
\text { ments beyond the prescriptions }\end{array}$ \\
\hline $\begin{array}{l}\text { What innovations } \\
\text { does it promote? }\end{array}$ & $\begin{array}{l}\text { - Spread of best available tech- } \\
\text { nologies }\end{array}$ & $\begin{array}{l}\text { - Development and spread of new } \\
\text { technologies, processes, and } \\
\text { products } \\
\text { - Innovations in company organisa- } \\
\text { tion }\end{array}$ \\
\hline $\begin{array}{l}\text { How well is it } \\
\text { accepted? }\end{array}$ & $\begin{array}{l}\text { - Accepted as the main element of } \\
\text { current environmental policy } \\
\text { - Resistance to increasing regula- } \\
\text { tion }\end{array}$ & $\begin{array}{l}\text { - Resistance to new costs } \\
\text { - Disagreement over the utilisation } \\
\text { of new revenue } \\
\text { - Increasing political acceptance }\end{array}$ \\
\hline $\begin{array}{l}\text { What efforts and } \\
\text { costs does it } \\
\text { involve? }\end{array}$ & $\begin{array}{l}\text { - Creating and instituting laws is } \\
\text { time-consuming } \\
\text { - Administrative costs }\end{array}$ & $\begin{array}{l}\text { - Creation of legal bases is time- } \\
\text { consuming } \\
\text { - Administrative costs covered by } \\
\text { revenues from taxes and charges } \\
\text { - Costs for subsidies }\end{array}$ \\
\hline
\end{tabular}

${ }^{1}$ Incentives can also be implemented by private organisations in the framework of campaigns and deposit-refund systems. 
(Table 3, cont.)

\begin{tabular}{|c|c|c|}
\hline $\begin{array}{c}\text { SERVICE AND INFRASTRUCTURE } \\
\text { INSTRUMENTS }\end{array}$ & COLLABORATIVE AGREEMENTS & $\begin{array}{l}\text { COMMUNICATION AND DIFFUSION } \\
\text { INSTRUMENTS }\end{array}$ \\
\hline $\begin{array}{l}\text {...because people can carry } \\
\text { out an action only if there is } \\
\text { the possibility to do so, and } \\
\text { because they prefer to make } \\
\text { use of attractive as opposed } \\
\text { to unattractive offers. }\end{array}$ & $\begin{array}{l}\text {...because people uphold } \\
\text { contracts. }\end{array}$ & $\begin{array}{l}\text {...because people pursue goals in } \\
\text { accordance with their perceptions, } \\
\text { categorisations, appraisals, and } \\
\text { knowledge. }\end{array}$ \\
\hline $\begin{array}{l}\text { 1. Public authorities } \\
\text { 2. Companies } \\
\text { 3. Public and private organi- } \\
\text { sations } \\
\text { 4. Individuals }\end{array}$ & $\begin{array}{l}\text { - Public authorities together } \\
\text { with companies }\end{array}$ & $\begin{array}{l}\text { 1. Public authorities } \\
\text { 2. Public and private organisations } \\
\text { 3. Individuals }\end{array}$ \\
\hline $\begin{array}{l}\text { 1. Individuals } \\
\text { 2. Companies } \\
\text { 3. Public and private organi- } \\
\text { sations }\end{array}$ & - Companies & $\begin{array}{l}\text { 1. Individuals } \\
\text { 2. Public and private organisations }\end{array}$ \\
\hline $\begin{array}{l}\text { - Effective if demand can be } \\
\text { created } \\
\text { - Once created, infrastruc- } \\
\text { tures are as a rule not re- } \\
\text { versible }\end{array}$ & $\begin{array}{l}\text { - Effective if legally binding } \\
\text { and if there are sanctions } \\
\text { for non-compliance } \\
\text { - Reaches only those com- } \\
\text { panies/branches involved } \\
\text { - Relatively flexible - quite } \\
\text { adaptable to specific situa- } \\
\text { tions }\end{array}$ & $\begin{array}{l}\text { - Effectiveness difficult to meas- } \\
\text { ure } \\
\text { - Effective quickly, but with limited } \\
\text { reach if applied in the framework } \\
\text { of action campaigns } \\
\text { - Effective in the long term if there } \\
\text { is a corresponding trend in } \\
\text { society } \\
\text { - Suited to supporting the accep- } \\
\text { tance and effectiveness of other } \\
\text { instruments }\end{array}$ \\
\hline $\begin{array}{l}\text { - New companies } \\
\text { - New institutions }\end{array}$ & $\begin{array}{l}\text { - Optimisation of processes } \\
\text { - Innovations in company } \\
\text { organisation } \\
\text { - New institutional arrange- } \\
\text { ments }\end{array}$ & $\begin{array}{l}\text { - New forms of social organisation } \\
\text { - New institutional arrangements } \\
\text { - Development and spread of new } \\
\text { technologies, processes, and } \\
\text { products }\end{array}$ \\
\hline $\begin{array}{l}\text { - Acceptance of attraction- } \\
\text { based forms } \\
\text { - Resistance to repulsion- } \\
\text { based forms }\end{array}$ & $\begin{array}{l}\text { - High acceptance by com- } \\
\text { panies, as long as less ex- } \\
\text { pensive than other meas- } \\
\text { ures }\end{array}$ & $\begin{array}{l}\text { - High acceptance of traditional } \\
\text { forms } \\
\text { - Hesitant acceptance of unfa- } \\
\text { miliar forms } \\
\text { - Resistance to new forms of par- } \\
\text { ticipation possible }\end{array}$ \\
\hline $\begin{array}{l}\text { - Investment and operating } \\
\text { costs }\end{array}$ & $\begin{array}{l}\text { - Negotiations can be tedious } \\
\text { and lengthy }\end{array}$ & $\begin{array}{l}\text { - Costs for planning and execut- } \\
\text { ing projects and action cam- } \\
\text { paigns } \\
\text { - Costs for education and re- } \\
\text { search }\end{array}$ \\
\hline
\end{tabular}

${ }^{2}$ or, for labels, public and private organisations together with companies. 
When the measures and instruments are introduced internationally at a later date, a country may profit from its "first mover advantage".

Despite the objections, the implementation of economic instruments has increased rapidly world wide in recent decades. In 1994 the OECD determined that, in general, OECD countries resort to measures of the command and control type to achieve changes in polluting behaviour. (OECD, 1994). Since then, market-based policy instruments have been on a steady rise. In a detailed review of existing measures, Stavins (2000) cites examples in dozens of countries, particularly European countries, that are being applied in the most diverse areas. We have to keep on mind that this impressive list of concrete applications of economic instruments looks at market-based instruments in the widest sense, that is, it includes instruments whose primary goals are fiscal. The Swiss Agency for the Environment, Forests and Landscape (SAEFL) reports that economic instruments are rapidly replacing statutory command and control instruments, especially since the Amendment to the Federal Environmental Protection Law in December 1995 (SAEFL, 1997).

\subsubsection{Service and infrastructure instruments}

The attraction based forms of service and infrastructure instruments have the advantage of being easily accepted by the target persons. Travelling by train because it is comfortable and fast is much more positive than travelling by train because there is no other alternative. However, the acceptance of the financing of service and infrastructure instruments cannot be taken for granted. The repulsion based forms of service and infrastructure instruments are no more easily accepted than command and control instruments and repulsion based economic instruments.

\subsubsection{Collaborative agreements}

Collaborative agreements are generally well accepted by industry, their main target group. The motivation of companies or industrial sectors to enter into negotiations often lies in the government's commitment to forego implementing other, more restrictive instruments. In contrast to taxes or other economic instruments, the industry also perceives an advantage in the fact that with agreements, no transfer of finances between the industry and the government takes place. Environmental organisations, on the other hand, are often sceptical of agreements.

\subsubsection{Communication and diffusion instruments}

Most forms of communication and diffusion instruments are generally well accepted by target groups as well as by political decision-makers, although there may be hesitancy when the instruments are not yet well known. Participatory processes may be rejected due to their inherent potential to alter the power relations between different actor groups. 


\subsection{What effort and costs does it involve?}

The application of policy instruments for achieving environmental goals always carries monetary and non-monetary costs. Of course, the amount of costs varies within each instrument type, but a few general observations can be made. Command and control, as well as economic and some infrastructure and service instruments, require legal bases, and the creation of these may be very timeconsuming. In addition, command and control and economic instruments generate administrative and technical costs, although in the case of taxes and charges these can be covered by the revenue created. Service and infrastructure instruments generate investment and operation costs. For reaching collaborative agreements, prolonged negotiations are sometimes required. Expenditures for implementing communication and diffusion instruments vary enormously and depend upon both the type of instrument and the size of the target group. Generally, it seems advisable to procure consulting services by specialists once the size of the target group reaches several hundred persons.

\subsection{Conclusion}

Clearly, the different types of instruments rely on quite different rationales, they have different ranges, and different actors are involved in their design and implementation. Another look at Table 1A-C (pages 40-45) and at Table 4 (page 90f.) reveals that - going from command and control to communication and diffusion instruments - there is a decrease in the instruments' capacity to influence the sphere of action of the target groups and a decrease in formal obligation created by the instrument. On the other hand, there is an increase in context-specificity and in multi-actor participation. It is clear that each of these features may have its specific advantages and disadvantages depending on the political situation and the specific problems that are addressed. There can be no single "best instrument" or general "best policy-mix". The "appropriate mix" has to be selected according to policy objectives and under consideration of the possible interactions (facilitating or inhibiting) between the different types of instruments. In other words, the appropriate selection of instruments, their design, and their timing must be embedded into a strategy, which requires first of all that policy goals be defined (see also Jänicke et al., 1999).

\section{Relationships to other typologies and classifications}

Knowledge on the rationale of different instruments and knowledge on their modes of operation is of course founded in various scientific disciplines and their respective theories, methods, and empirical findings. It would go beyond the scope of this volume to review this multidisciplinary background. However, we would like to provide the interested reader with some guidance by pointing 
out the major sources and relevant approaches. They are selected mainly from jurisprudence, the political sciences, economics, and psychology (see also König and Dose, 1993, for a detailed review of various classifications used in jurisprudence, economy, political science, sociology, the sociology of law, and administrative science).

\subsection{Jurisprudence}

The legal perspective focuses first of all on who implements a certain policy instrument and on the legal consequences of the instrument. In other words, in view of the law, it is important to determine if the instrument creates rights and obligations of the target group, how the legal relationships arise, and what the content of the rights and obligations are. "Law" signifies a binding and - as a rule-enforceable social arrangement. There is thus an important differentiation between legal obligations and behavioural norms based upon other premises not enforceable by the state. These may involve, for example, ethical or moral considerations or obligations.

It is the duty of the state to implement consensus arrived at through the political process. This duty must be expressed in its regulatory activities, even if instruments other than statutory prohibitions and prescriptions are implemented. Self-regulation is politically popular, because it seems to be a way to turn over the regulation of a problem to the actors and all those involved themselves. In terms of enforceability and implementation, however, the concept of self-regulation has inherent limits: a person not willing to voluntarily adhere to a regulation can not be forced to comply as long as there is no legal, enforceable basis.

\subsubsection{Forms of government action}

In a legal perspective, government actions at the levels of federal government, canton, and municipality can take various forms, but there are no limits to the number of forms of action. Traditionally, the following categories are distinguished:

Statutes: Through statutes, or laws, the state regulates a certain area in a general and abstract way for all involved. This is the wider sense of the term "law" that comprises constitutions, formal laws and statutes, ordinances, and more. Law making is a classic function of the state that can be exercised at various democratic levels (all eligible voters, parliament, government).

Orders, directions, acts decreed: Through orders, the state defines the individual rights and obligations of private persons in individual cases. Orders may involve burden (assessing taxes, assessing of contested fees) or favour (license to construct, license to operate). Through orders the state again acts on the basis of the legitimate power monopoly and sovereign capacity to which it is entitled, independently of the will of the person involved. Orders therefore always require democratic legitimatisation and a legal basis. The administration is responsible for the issuing of orders.

Transitional forms between statutes and orders: Some forms show the features of laws and orders. Some examples are land use plans, or zoning regulations, which define the options for 
land use in particular areas, and general decrees (such as prohibition of driving in a neighbourhood street).

Contract: Similar to orders, through contracts the state determines the rights and obligations of private persons. In contrast to the order, however, contracts are not issued in a sovereign manner, but are drawn up with the agreement of the other party. Contractual regulations do not necessarily require an explicit legal basis, but they must not contradict the law.

De facto administrative action [Realakt]: Unlike the above forms, administrative action does not define rights or obligations, but rather supplies services. For example, the state supplies drinking water and energy, purifies wastewater, and provides public education.

It is relatively easy to assign classical instruments to the traditional categories of government activity. Command and control instruments in our typology belong primarily to the category of statute, or law. An exception is licensing (license to construct, license to sell), which in the concrete case may be issued in the form of an order. The economic instruments are implemented in the main in the form of orders (which, as mentioned, require a legal basis). With regard to content, economic instruments may be categorised as burden or favour and also according to the nature of the rights and obligations (financial, other). For instance, subsidies represent a financial favour, while taxes and charges entail a financial burden. Licenses are favourable orders with a different content, and burden may be attached to them. Market creation can be assigned in part to the legal form of a law, not an order, as it regulates a "competitive system" in a general and abstract manner.

The newer instruments, in particular communication and diffusion instruments and collaborative agreements, can be categorised as contracts insofar as binding rights and obligations are contracted. Otherwise, in the traditional categorisation they fall under "de facto administrative actions". It is often not possible to draw exact lines, because various instruments also contain contractual elements. In the science of jurisprudence, government activities in the area of information, motivation, and concrete recommendations have recently come to be known as "informal administrative actions". From the perspective of jurisprudence, these actions constitute a grey zone of administrative law (although not outside the realm of the law) that stands in a relationship of potential tension to the legality principle as defined in the constitution (Müller, 1995: 361).

\subsubsection{Legal base of government action}

For the state there is no sphere of action outside a legal framework. State actions are admissible only if they serve directly or indirectly to fulfil public duties or functions. Public duties and functions are determined by the law as a "concentrated" result of a political process. According to the legality principle, academic law and court decisions today demand that all administrative action, not only administrative interference (interference with civil liberties and other rights of citizens), but also administrative benefits and services (such as state services in education or public assistance), have a legal basis. This legal basis may in some cases be very general in nature. New instruments of informal administrative action as well as the collaborative agreements and communication and 
diffusion instruments described in this chapter also ultimately require a (more or less general) legal basis.

Besides this required legal basis, communication and diffusion instruments may be implemented only under consideration of certain legal principles. In all cases, public authorities are bound to observe the fundamental rights of citizens, equal treatment of all citizens, and the prohibition against arbitrariness. For example, tax reductions for environmentally sound practices may not be granted at will and from case to case, but only on the basis of special statutory power and in factually justified cases. If the state issues awards or certificates for a certain product or activity, it may not put competitors at a disadvantage for no evident reason. Depending upon relevance to fundamental civil rights, the legal demands will be formulated more or less strictly. In this respect, it is relatively unproblematic for a Federal Councillor to demonstrate how eggs can be cooked using less energy. But if a public authority warns the public about consumption of a particular sort of soft cheese in an effort to ward off a listeriosis epidemic, and this results in a massive drop-off in sales of the product, the situation is very different (see Schweizerische Bundeskanzlei, 1987: 97ff.).

It is also important to note that various instruments require a special legal basis. For implementation of instruments that have fiscal consequences, for instance, a decree by the fiscal authorities is always a prerequisite. Government information and motivating programmes, particularly government recommendations, raise some special issues. The body politic may represent certain "values", such as ecological concerns, of course, but it must observe the principle of neutrality (in worldview) and the factual nature of the information. In referendums, information provided by the government about the bill that goes beyond the official statement is admissible only as an exception, because public authorities may not interfere with the freedom of the public to form an opinion. The Federal Court has declared it inadmissible, for example, for cantonal authorities to publish quite objective information in the newspaper prior to the referendum vote. In this connection, recent voices in the field of law have suggested that more weight should be placed on public authorities' obligation to inform the public (Decurtins, 1992).

Many instruments of informal administrative action in the areas of communication and diffusion instruments and collaborative agreements are relatively new to the field of jurisprudence and have not yet undergone extensive legal examination (but see Müller, 1995; Nützi, 1995; Pfenninger, 1996; and their references to the literature). Up to now, it has been the exception and not the rule for these instruments to be regulated in an expressly legal and binding manner. There is, however, the "co-operation principle", which has been anchored in the Environmental Protection Law in 1997 (Art. 41a of this law). In line with this provision, the Confederation and the cantons work together with organisations in the economy. Through setting quantity targets and corresponding time limits, they can promote agreements with various branches of industry. Prior to issuing regulations for execution, they examine voluntary measures by the economic partners, and whenever possible and necessary the agreements are incorporated into the implementing law either in part or in their entirety. 


\subsection{Political Sciences}

In the political sciences, especially in recent research on the policy implementation process, there has been lively discussion on the classification of policy instruments. The focus is on the state as actor who tries to influence the behaviour of actors outside of the political-administrative system. Usually the action possibilities of public authorities are looked at in detail, while the scope of action of those to be influenced is not the object of reflection. However, there is neither consensus on a specific typology nor dominance of one of them.

For analytical purposes, Varone (1998: $33 \mathrm{ff}$.) distinguishes two kinds of typologies: one focuses on nominal categories, the other on fundamental attributes. Nominal categories may be elaborated on the basis (1) of resources needed for the implementation of an instrument (Hood, 1983), (2) of the degree of legitimate constraint (Doern and Phidd, 1983), (3) of the expected effects of an instrument (McDonnell and Elmore, 1987), or (4) of the behavioural aptitudes of the target groups (Ingram and Schneider, 1990). Among the typologies concentrating on attributes, Varone mentions Sabatier and Pelkey's (1987) advocacy coalition approach, Salamon's (1989) public management approach, Linder and Peters' (1989) policy design, and Trebilcock's et al. (1994) public choice theory. Our typology shows some analogies to the constraint-based continuum proposed by Doern and Phidd (1983), but combines that with further elements from various other typologies. With a particular focus on the German literature and the traditional instruments, Kaufmann and Rosewiz (1983) give an overview of classifications that have been important in the discourse within the political sciences. One of their conclusions is that attempts to develop very generalised typologies that are independent of the domain, goals, and contents of policy-making might not be as fruitful as less generalised classifications that are closer to reality. Their own typology is on social policy, where they distinguish among legal, economic, ecological, and educational instruments (Kaufmann and Rosewitz, 1983: 45). Dahme and Grunow (1983) have presented a thorough analysis of the implementation of "persuasive programmes" that use the more or less conventional instruments for influencing knowledge and capacities (providing information, education, training, consulting, and so on) in the domain of health and consumer education.

For the domain of environmental policy, the usual distinction made is between regulatory and economic instruments as "classical" policy instruments, with mention of a heterogeneous class of “new” instruments (Dente, 1995; Jänicke and Weidner, 1995; Jänicke et al., 1999: 101) point out that in the political sciences, instruments are usually ordered according to the degree of governmental regulation of behaviour, ranging between the poles of coercion and voluntariness. Their proposal distinguishes the following main types of environmental policy instruments: regulatory law instruments (high degree of state control), planning instruments (state control medium to high), economic instruments (state control medium), co-operation (state control medium to low), and information (low degree of state control). It is obvious that this typology is quite similar to the one we propose, the main difference being that service and infrastructure instruments are not included, 
and that our "communication and diffusion instruments" are broader and go beyond "information".

Klok (1995) criticises existing typologies for classifying instruments according to one or a few differentiating characteristics and neglecting characteristics that they have in common, and for being more or less closed systems unable to incorporate new instruments that emerge in the political praxis. His understanding is that a classification "is not a set of sharply deliminated and exclusive cells, but a method for the characterisation of policy instruments (showing differences and similarities)" (p. 21). He then introduces a simple model of human action that assumes that all human activity is the result of (internal and external) motivations and resources (physical goods, skills, information, time, and social resources, such as money, legal rights, or trust). Using this model, political measures can be characterised as influencing the actors' resources and/or motivation by conditional or unconditional provision or deprivation of resources. This approach shares some similarities with our own, as it relates the description of instruments to what they should influence, namely human action. Klok's extremely broad concept of "resources" is interesting theoretically in view of economic as well as psychological action models. For practical purposes, however, it might be too one-dimensional, because the concrete measures that provide or withdraw various types of resources are probably very different: providing trust, for example, requires completely different measures than providing money.

Another analysis and classification of public policy instruments has been presented by Vedung (1998). As in our approach, the dimension underlying his division is the degree of constraint intended by the policymakers. Attempting to offer a parsimonious classification, he suggests that not more than three basic types of instruments be distinguished: regulations (the "sticks"), economic means (the "carrots"), and information (the "sermons"). It is obvious that these types correspond more or less to our command and control, economic, and communication and diffusion instruments. Our service and infrastructure instruments would be classified by Vedung as economic instruments, as they can be regarded as providing or withdrawing non-monetary resources: "A bump in the road to prevent motorists from speeding is an economic instrument just as a tax levied on gasoline is" (Vedung, 1998: 33). Negotiations leading to agreements or labels would be regarded as "governing through persuasion" (ibid: 37), i.e., as belonging to the information type of instruments. Vedung and van der Doelen (1998) analyse and discuss "information" as a public policy instrument that "covers government-directed attempts at influencing people through transfer of knowledge, communication of reasoned argument, and moral suasion in order to achieve a policy result" (Vedung and van der Doelen, 1998: 103). Concentrating on the forms of informationdispensing available to public authorities, they distinguish several sub-types quite similar to the ones that we propose for diffusion instruments. 


\subsection{Economics}

The extensive literature on economics - and in particular on market-based instruments - presents a myriad of typologies too numerous to describe in detail. They often differ only on minor points. There are three basic approaches: (1) theory based approaches, (2) approaches based upon concrete criteria, and (3) experience based approaches.

\subsubsection{Theory based approaches}

This approach is often found in basic research, which describes the economic fundaments and mechanisms of these instruments. The objective is "to provide a systematic treatment of the theory of externalities and its implications" (Baumol and Oates, 1993: 2) in order to facilitate discussion of the theoretical advantages of economic instruments in regard to eco-efficiency and their effect upon income distribution. ${ }^{13}$ The types of instruments are divided into broad categories. Tietenberg (1990) uses the categories of Emissions Trading and Emissions Charges; Baumol and Oates (1993) add subvention as a third category. Tietenberg also makes a distinction between "efficiency charges", designed to produce an efficient outcome to totally compensate for damage, and "costeffective-charges" to achieve a predefined goal at the lowest possible cost. This distinction is theoretical, however, and does not correspond to instruments that are in fact applied. This is indeed the main difference between this approach and our own typology, which does not base upon theoretical aspects, but rather upon concrete applications and mechanisms.

\subsubsection{Approaches based upon concrete criteria}

A second approach comprises typologies that, while they do employ concrete criteria, do not differentiate among all possible applications. For example, Lohman (1994) distinguishes among "financial instruments", which are all introduced with the exclusive purpose of financing specific, environmental tasks, "economic incentives", designed to create an incentive effect, and a mixed category for financial instruments that produce incentives as a side-effect.

Turner and Oschor (1994) distinguish instruments according to the type of influence on the market. These influences are direct modification of prices and costs, indirect influencing through fiscal means, and finally, market creation and support. To the direct modifications belong charges on products and processes (emissions charges) and deposit-refund systems. Indirect changes result from subvention and also from enforcement incentives (non-compliance fees and performance bonds). Market creation includes emissions trading and quota auctioning. Stabilisation of prices, such as for recycling products, is described as market support. Jeanrenaud (1997) forms three categories of environmental policy instruments according to the role of the state: (1) direct government intervention, that is, expenditures by the state to create, operate, and maintain infrastruc-

13 For the reader interested in economic theory, Bohm and Russel (1985) and Christainsen and Tietenberg (1985) provide extensive lists of references. 
tures (public anti-pollution investment) and to finance research; (2) measures to change practices (behaviour modification), including information and moral suasion, command-and-control, incentive-based regulations, and privatisation, whereby the incentive-based regulations include all of the "classical" economic instruments (charges, tradable permits, deposit-refund systems, joint implementation); and (3) "laissez-faire", where the actors influenced participate voluntarily, and the role of the state is restricted to defining clear property rights and liability for damages.

Our typology, which distinguishes among the instruments according to the effecting mechanisms, makes use of these approaches in part. For instance, our distinction of taxes and charges corresponds to distinction of financial versus economic instruments made by Lohman (1994). The categorisations by Turner and Oschor (1994) and Jeanrenaud (1997) are also reflected in our typology, although in more detailed forms. With regard to Jeanrenaud's typology, we have to say that in our understanding, all environmental policy instruments aim for behavioural modification, whether they are coerced or voluntary.

\subsubsection{Experience based approaches}

The third approach distinguishes among types of instruments that find application in reality. Here we find the various OECD instrument evaluation studies (for example, OECD, 1997b), whose typology has often been adopted, expanded, and modified. The OECD names four categories of economic instruments: charges/taxes (emission charges/taxes, user charges/taxes, product charges/taxes), subsidies (grants, soft loans, tax allowances), tradable emission permits, and deposit-refund systems. It should be noted that the terms "charges" and "taxes" are used synonymously, whereby the sub-category "user charges" is defined as "charges that are payments for the costs of collective or public treatment of effluent or waste" (OECD, 1997b: 16), which corresponds to our sub-type of charges. ${ }^{14}$

One of the most detailed typologies with the most examples of applications is that by Stavins (2000). Stavins divides the instruments into the four categories of charge systems, tradable permit systems, reducing market barriers, and reducing government subsidies. Charge systems comprise taxes, charges, and subventions (with definitions similar to our own typology), and also insurance premium taxes, which are designed to encourage companies to internalise environmental risks in their own decision making. Tradable permit systems subsume credit programmes (an emissions

14 Other OECD publications distinguish:

Taxes: The OECD classification (as used in the annual OECD publication, Revenue Statistics) defines taxes as "compulsory, unrequited payments to general government. Taxes are unrequited in the sense that benefits provided by government to taxpayers are not normally in proportion to their payments" (OECD, 1997a: 18). Note that a tax (unrequited) can be earmarked if it is decided that a certain percentage of the revenue will be used for a specific purpose (e.g., when part of a gasoline tax is earmarked for road construction).

Charges/fees: The OECD classification also uses the terms "fees" and "user charges" (as opposed to "taxes") and "levies" without giving a precise definition of these terms. In practice, the terms "charges" and "fees" are often used interchangeably: "Charges and fees are compulsory requited payments, i.e., a service is provided in proportion of the payment. Charges can also be paid into specific "funds" and earmarked for specific environmental purposes" (OECD, 1997a: 18). 
source gets credits if it can reduce its polluting below a set level; credits can be used by other emission sources) and cap-and-trade systems (a general pollution threshold is set and assigned to companies in the form of tradable licenses). Reducing market barriers includes market creation (measures to facilitate voluntary trading of water rights), liability rules, and information programmes (information obligation, labelling). Reducing government subsidies applies mainly to third world countries, in cases where individual production branches were protected by subventions despite their environmental impact (coal production in China, for instance).

This latter typology includes all the economic instruments in our own typology with the exception of incentives as parts of action campaigns. This is because their influence can not be measured at the macroeconomic level, and because they are not normally implemented by the state. The instruments are described in more detail and finer distinctions are made, such as for tradable permits and reducing subventions. Our typology focuses upon applications and application possibilities at the local and national levels, and for this reason it places less weight upon instruments that at this time are implemented mainly in North America and in third world countries. Insurance premium taxes, liability rules, and information programmes are instruments that in our typology do not fall in the category of economic instruments.

\subsection{Psychology}

Psychology focuses on describing, understanding, predicting, and eventually influencing individual behaviour. Traditionally, it has not dealt with policy instruments, because these are regarded as part of the milieu or situation within which individual behaviour takes place, and as such are not taken as psychological factors. Within the relatively recent development of environmental psychology, however, psychologists have begun to think about applying their knowledge on how to induce behaviour change to the field of achieving environmental goals (Mosler and Gutscher, 1998). New forms of interventions based on principles of behavioural and social psychology have been developed in order to complement traditional environmental policy instruments or to enhance their effectiveness (see the chapter by FLURY-KLEUBLER AND GUTSCHER for an overview and discussion of such principles and Stern, 2000a, for a general discussion of the contribution of psychology to the resolution of environmental issues). Geller and his colleagues (Geller et al., 1982; Geller, 1987; Geller, 1989) were among the first to present an approach based on behavioural analysis, which makes use of well founded principles of behaviour modification. Combining such an approach with principles used in marketing leads to "social marketing" which is finding increasing application in environmental contexts (Kotler and Roberto, 1991; Prose et al., 1994; McKenzie-Mohr and Smith, 1999). Social marketing mainly applies instruments that we subsume under "communication instruments", "service and infrastructure instruments", or - in cases of monetary incentives under "economic instruments". 
Gardner and Stern (1996) have presented a very broad overview of psychological knowledge relevant to understanding and solving environmental problems. Without setting out an explicit typology of instruments, they strongly recommend a combination of "solution strategies" for promoting behavioural changes, whereby emphasis is placed on the importance of participatory methods and networking. Gardner and Stern outline four types of approaches to be used in combination:

By religious and moral approaches they understand all attempts to change values, beliefs, and worldviews, especially the influence of pro-environmental movements on public opinion about environmental issues.

Educational interventions aim at providing information effectively by using feedback, modelling, and framing messages, ${ }^{15}$ and at tightening the links between attitudes and behaviour through reminders and prompts, public commitment, and highlighting attitudes and norms.

By changing incentives, Gardner and Stern (1996) refer not only to the classic economic instruments (like taxes and subsidies), but also to what we mean by service and infrastructure instruments: They stress the importance of making environmentally responsible behaviour as convenient - and thus rewarding - as possible. Their understanding of "incentive" has its roots in the concept of operant conditioning (Skinner, 1969), which states that behaviour is shaped by the consequences it has. Therefore, the authors also seem to view the command and control instruments of our typology as "incentives", although they do not treat them explicitly.

Community management of the commons is treated as a means to overcome the socio-ecological dilemmas leading to the overuse of common resources and the "tragedy of the commons" (Hardin, 1968). Gardner and Stern (1996) recommend the application of participatory methods and networking and an approach to the problems that is - wherever possible - at the local level rather than at the state or national level.

Based on their analysis of a number of model intervention programmes, Gardner and Stern (1996) list the principles or "success factors" for interventions that aim at changing environmentally undesirable behaviour as presented in Table 4. These principles call for the intelligent application and combination of different instruments. Principle $\mathrm{C}$ requires the use of communication and diffusion instruments (which - as we have seen - influence primarily the internal (psychological) structure of the actors), while for realising principle $\mathrm{D}$, instruments targeted primarily at the external structure are needed.

15 Framing refers to how pro-environmental behaviours are described, such as referring to "energy efficiency", a desirable goal, instead of "conservation", which many people associate with sacrifice. 
Table 4: Principles for intervening to change environmentally destructive behaviour (from Gardner and Stern, 1996: 159).

\begin{tabular}{|l}
\hline A. Use multiple intervention types to address the factors limiting behaviour change \\
- Limiting factors are numerous (e.g., technology, attitudes, knowledge, money, con- \\
venience, trust) \\
- Limiting factors vary with actor and situation, and over time \\
- Limiting factors affect each other (interactive principle) \\
B. Understand the situation from the actor's perspective \\
- Conduct surveys or experiments \\
C. Participatory approach to program design \\
- When limiting factors are psychological, apply understanding of human processes \\
- Apply principles of community management (credibility, commitment, face-to-face \\
D. Address conditions beyond the individual that constrain pro-environmental choice \\
E. Set realistic expectations about outcomes \\
F. Continually monitor responses and adjust programs accordingly \\
G. Stay within the bounds of the actors' tolerance for intervention \\
H. Use participatory methods of decision making
\end{tabular}

\section{References}

Aronson, E. and O'Leary, M. (1983) The relative effectiveness of models and prompts on energy conservation: A field experiment in a shower room. Journal of Environmental Systems, 12: 219-224.

Bachmann, W. and Katzev, R. (1982) The effects of non-contingent free bus tickets and personal commitment on urban bus ridership. Transportation Research, 16A: 103-108.

Baltes, M.M. and Haywood, S.C. (1976) Application and evaluation of strategies to reduce pollution: Behavioral control of littering in a football stadium. Journal of Applied Psychology, 62: 501-506.

Balthasar, A. and Knöpfel, C. (1994) Umweltpolitik und technische Entwicklung. Eine politikwissenschaftliche Evaluation am Beispiel der Heizungen. Helbing and Lichtenhahn, Basel.

Bandura, A. (1986) Social foundations of thought and action. Prentice-Hall, Englewoods Cliffs, NJ.

Bättig, Ch. (2001) Fallstudie Evaluation der Verbrauchszielwerte, Fallstudie in Netzwerkmanagment als neues Instrument der Umweltpolitik. Interface, Luzern; in prep.

Baumol, W.J. and Oates, W.E. (1993) The theory of environmental policy. Cambridge University Press, Cambridge, New York.

Bemelmans-Videc, M.-L., Rist, R.C. and Vedung E. (eds.) (1998) Carrots, sticks and sermons. Policy instruments and their evaluation. Transaction Publishers, New Brunswick, New Jersey.

BFE/Bundesamt für Energie (1998a) Freiwillige Massnahmen unter besonderer Berücksichtigung von Vereinbarungen. Internes Arbeitsdokument BFE, Januar 1998, Bern.

BFE/Bundesamt für Energie (1998b) Organisation und Vollzug des Energiegesetzes und Zusammenarbeit mit Externen (OVE). Internes Arbeitsdokument BFE, Juni 1998, Bern.

Bohm, P. and Russel, C.S. (1985) Comparative analysis of alternative policy instruments. In: Handbook in natural resource and energy economics, Kneese, A.V. and Sweeney, J.L. (eds), North Holland.

Burn, S.M. (1991) Social psychology and the stimulation of recycling behaviors: The block leader approach. Journal of Applied Social Psychology, 21: 611-629.

Burn, S.M. and Oskamp, S. (1986) Increasing community recycling with persuasive communication and public commitment. Journal of Applied Social Psychology, 16: 29-41.

Christainsen, G.B. and Tietenberg, T.H. (1985) Distributional and macroeconomic aspects of environmental policy. In: Handbook in natural resource and energy economics, Kneese, A.V. and Sweeney, J.L. (eds), North Holland. 
Cialdini, R.B., Reno, R.R. and Kallgren, C.A. (1990) A focus theory of normative conduct: Recycling the concept of norms to reduce littering in public places. Journal of Personality and Social Psychology, 58: 1015-1026.

Dahme, J. and Grunow, D. (1983) Implementation persuasiver Programme. In: Implementation politischer Programme II, Mayntz, R. (ed.), Westdeutscher Verlag GmbH, Opladen.

De Clercq, M. (1996) The implementation of green taxes: The Belgian Experience. In: Environmental taxes and charges. National experiences and plans, The European Foundation for the Improvement of Living and Working conditions (eds.), Luxembourg.

Decurtins, G.-A. (1992) Die rechtliche Stellung der Behörde im Abstimmungskampf. Universitätsverlag, Freiburg (Schweiz).

Dente, B. (ed.) (1995) Environmental policy in search of new instruments. Kluwer Academic Publishers, Dordrecht, Boston, London.

Diamond, W.D. and Loewy, B.Z. (1991) Effects of probabilistic rewards on recycling attitudes and behavior. Journal of Applied Social Psychology, 21: 1590-1607.

Doern, B.C. and Phidd, R.W. (1983) Canadian public policy. Ideas, structure, process. Methuen, Toronto.

Dwyer, W.O., Leeming, F.C., Cobern, M.K., Porter, B.E. and Jackson, J.M. (1993) Critical review of behavioral interventions to preserve the environment. Research since 1980. Environment and Behavior 25/3: 275-321.

ECONCEPT and IPSO (1997) Evaluation energiepolitisch motivierter Steuererleichterungen. Studie für das Schweizer Bundesamt für Energie im Rahmen der Evaluation des Aktionsprogramms Energie 2000, Zürich und Dübendorf.

ECOPLAN (1993) Abwasserabgabe für die Schweiz - Lenkung, Finanzierung und Ausgleich in der Abwasserentsorgung. Schriftenreihe Umwelt, Nr. 203. Bundesamt für Umwelt, Wald und Landschaft, Bern.

Everett, P.B., Hayward, S.C. and Meyers, A.W. (1974) The effects of a token reinforcement procedure on bus ridership. Journal of Applied Behavior Analysis, 7: 1-9.

Gardner, G.T. and Stern, P.C. (1996) Environmental problems and human behavior. Allyn and Bacon, Boston.

Geller, E.S. (1987) Applied behavior analysis and environmental psychology - From strange bedfellows to a productive marriage. In: Handbook of environmental psychology, Stokols, D. and Altmann, I. (eds.), John Wiley and Sons, New York.

Geller, E.S. (1989) Applied behavior analysis and social marketing: An integration for environmental preservation. Journal of Social Issues 45: 17-36.

Geller, E.S., Winett, R.A. and Everett P.B. (1982) Preserving the environment. New Strategies for behavior change. Pergamon Press, New York.

Glasbergen, P. (ed.) (1998) Co-operative environmental governance. Public-private agreements as a policy strategy. Kluwer, Dordrecht.

Gonzales, M.H., Aronson, E. and Costanzo, M.A. (1988) Using social cognition and persuasion to promote energy conservation: A quasi-experiment. Journal of Applied Social Psychology, 18: 1049-1066.

Grossman, D. and DeGaetano, G. (1999) Stop teaching our kids to kill: A call to action against TV, movie and video game violence. Crown, New York.

Gutscher, H., Keller, C. and Mosler, H.-J. (2000): Roads as new common pool resources, speed reduction as a public good -2 case studies in organizing large-scale collective action. Available: CD: 8th Biennial conference of the International Association for the Study of Common Property (IASCP), Indiana University, Bloomington, Indiana. Online in the WWW at: <http://129.79.82.27/IASCP/Papers/gutscherh041300.pdf>

Haefeli, U., Matti, D. and Seewer, U. (2000) Die Sanierung und Umgestaltung der Seftigenstrasse. Auswirkungen auf Lebensqualität und Einkaufsverhalten der NutzerInnen (mit besonderer Berücksichtigung des Langsamverkehrs und der Ertragssituation des Detailhandels). Schlussbericht der Wirkungsanalyse. IKAÖ, GIUB, Universität Bern.

Hardin, G. (1968) The tragedy of the commons. Science 162: 1243-1248.

Hasler, P.D. and Wälti, M. (1999) Machbarkeitsstudie Autohaltestellen. büro für utopien, Markwalder und Partner AG, Burgdorf.

Hood, C. (1983) The tools of government. MacMillan, London.

Hopper, J.R. and Nielsen, J.M. (1991) Recycling as altruistic behavior: Normative and behavioral strategies to expand participation in a community recycling program. Environment and Behavior 23: 195-220. 
Ingold, P. (1999) Freizeitaktivitäten und Naturschutz. Mitteilungen der Naturforschenden Gesellschaft in Bern, Neue Folge 56: 77-158.

Ingram, A. and Schneider, H. (1990) Improving implementation through framing smarter statutes. Journal of Public Policy 10/1: 333-356.

IEA/International Energy Agency (1989) Energy and the environment: Policy overview. OECD, IEA, Paris.

IEA/International Energy Agency (1997) Voluntary actions for energy-related $\mathrm{CO}_{2}$ abatement. OECD, Paris.

Jacobs, H.E. and Bailey, J.S. (1982-1983) Evaluating participation in a residential recycling program. Journal of Environmental Systems, 12: 141-152.

Jänicke, M. and Weidner, H. (eds.) (1995) Successful environmental policy. Rainer Bohn Verlag, Berlin.

Jänicke, M., Kunig, P. and Stitze, M. (1999) Umweltpolitik. Politik, Recht und Management des Umweltschutzes in Staat und Unternehmen. Dietz, Bonn.

Jeanrenaud, C. (1997) Economic instruments for environmental policy. In: Environmental policy between regulation and market, Jeanrenaud, C. (ed.), Birkhäuser, Basel.

Jepson, C. and Chaiken, S. (1990) Chronic issue-specific fear inhibits systematic processing of persuasive communications. Journal of Social Behavior and Personality, 5: 61-84.

Kantola, S.J., Syme, G.J. and Campbell, N.A. (1984) Cognitive dissonance and energy conservation. Journal of Applied Psychology, 69/3: 416-421.

Katzev, R.D. and Pardini, A.U. (1987-1988) The comparative effectiveness of reward and commitment approaches in motivating community recycling. Journal of Environmental Systems, 17: 93-113.

Kaufmann, F.-X. and Rosewitz, B. (1983) Typisierung und Klassifikation politischer Massnahmen. In: Implementation politischer Programme II. Ansätze zur Theoriebildung, Mayntz, R. (ed.), Westdeutscher Verlag, Opladen.

Kaufmann-Hayoz, R., Häuselmann, C. and Gessner, W. (1996) "Eco-Design” - die wahrnehmungspsychologische Erweiterung eines technischen Konzepts. In: Naturbilder. Ökologische Kommunikation zwischen Ästhetik und Moral. Themenhefte zum Schwerpunktprogramm Umwelt, Lesch, W. (ed.), Birkhäuser, Basel.

Kirchgässner, G. (1997) Environmental policy in Switzerland: Methods, results, problems and challenges. In: Economic policy in Switzerland, Bacchetta, P. and Wasserfallen, W. (eds.), Macmillan Press, Houndmills.

Klok, P.J. (1995) A classification of instruments for environmental economic policy. In: Environmental policy in search of new instruments, Dente, B. (ed.), Kluwer Academic Publishers, Dordrecht.

Kobi, F., Künzler, P. and Dietiker, J. (1995) Das Berner Modell - Die angebotsorientierte Verkehrsplanung als Instrument zur Reduktion der Umweltbelastungen durch den Verkehr. VDI Berichte, 1228: 195-215.

Kohlhaas, M. and Praetorius, B. (1994) Selbstverpflichtungen der Industrie zur $\mathrm{CO}_{2}-$ Reduktion. Sonderheft 152. Deutsches Institut zur Wirtschaftsforschung, Berlin.

Kok, G. and Siero, S. (1985) Tin recycling: Awareness, comprehension, attitude, intention and behavior. Journal of Economic Psychology, 6: 157-173.

König, K. and Dose, N. (1993) Instrumente und Formen staatlichen Handelns. Carl Heymanns Verlag, Köln.

Kotler, P. (1978) Marketing für Nonprofitorganisationen. Poeschel, Stuttgart.

Kotler, P. and Roberto, E. (1991) Social marketing. Econ, Düsseldorf.

Leventhal, H. (1970) Findings and theory in the study of fear communications. In: Advances in experimental social psychology, Vol. 5, Berkowitz, L. (ed.), Academic Press, New York.

Ligteringen, J.J. (1999) The feasibility of Dutch environmental policy instruments. Decreasing the environmental impact of households. Twente University Press, Enschede.

Linder, S.H. and Peters, G.B. (1989) Instruments of government. Perceptions and contexts. Journal of Public Policy, 9/1: 35-58

Lohman, L.d.S. (1994) Economic incentives in environmental policy: Why are they white ravens? In: Economic incentives and environmental policies: Principles and practice, Opschoor, J.B. and Turner, R.K. (eds), Kluwer Academic Publisher, Dordrecht, Boston, London.

Mayntz, R. (1980) Implementation politischer Programme: Empirische Forschungsberichte. Verlagsgruppe Athenäum Hain Scriptor Hanstein, Königstein/Ts.

Mayntz, R. (1983) Implementation politischer Programme II. Westdeutscher Verlag, Opladen.

McDonnell, L.M. and EImore, R.F. (1987) Alternative policy instruments. Center for Policy Research in Education, Santa Monica.

McKenzie-Mohr, D. and Smith, W. (1999) Fostering sustainable behavior. An introduction to communitybased social marketing. New Society Publishers, Gabriola Island B.C. 
Midden, C.J., Meter, J.E., Weening, M.H. and Zieverink, H.J. (1983) Using feedback reinforcement and information to reduce energy consumption in households: A field experiment. Journal of Economic Psychology, 3: 65-86.

Mosler, H.-J. and Gutscher, H. (1998) Umweltpsychologische Interventionsformen für die Praxis. Umweltpsychologie, 2: 64-79.

Mosler, H.-J. and Gutscher, H. Der Einsatz von Selbstverbreitungs- und Interventionsinstrumenten bei einer Energiesparaktion; in prep.

Müller, M. (1995) Staatliche Empfehlungen. Gedanken zu Rechtscharakter und Grundrechtsrelevanz. Zeitschrift für Schweizerisches Recht, I: 357-405

Nützi, P. (1995) Rechtsfragen verhaltenslenkender staatlicher Information: Strukturen, Zulässigkeit, Haftung. Verlag Stämpfli, Bern.

OECD/Organisation for Economic Co-operation and Development (1994) Managing the environment. The role of economic instruments. OECD, Paris.

OECD/Organisation for Economic Co-operation and Development (1997a) Environmental taxes and green tax reform. OECD, Paris.

OECD/Organisation for Economic Co-operation and Development (1997b) Evaluating economic instruments for environmental policy. OECD, Paris.

OECD/Organisation for Economic Co-operation and Development (1999) Voluntary approaches for environmental policy: An assessment. OECD, Paris

O'Keefe, D.J. (1990) Persuasion. Theory and research. Sage, Newbury Park.

Pallak, M.S. and Cummings, W. (1976) Commitment and voluntary energy conservation. Personality and Social Psychology Bulletin, 2: 27-30.

Pallak, M.S., Cook, D.A. and Sullivan, J.J. (1980) Commitment and energy conservation. Applied social psychology annual, $1: 235-253$.

Pardini, A.U. and Katzev, R.D. (1983-1984) The effect of strength of commitment on newspaper recycling. Journal of Environmental Systems, 13: 245-254.

Pfenninger, H. (1996) Rechtliche Aspekte des informellen Verwaltungshandelns: Verwaltungshandeln durch informell-konsensuale Kooperation unter besonderer Berücksichtigung des Umweltschutzrechts. Universitätsverlag, Freiburg (Schweiz).

Pigou, A.C. (1952) The economics of welfare, fourth edition. MacMillan, London

Prose, F., Kupfer, D. and Hübner, G. (1994) Social Marketing und Klimaschutz. In: Gesellschaftliche Aspekte von Klimaveränderungen, Fischer, W. and Schütz, H. (eds.), Forschungszentrum Jülich, Jülich.

Prose, F. and Wortmann, K. (1992) "Negawatt statt Megawatt": Eine Energiesparlampen-Aktion. In: Jahrbuch Ökologie, Altner, G., Mettler-Meibom, B., Simonis, U.E. and v. Weizäcker, E.U. (eds.), Beck’sche Reihe, München.

Rennings, K., Brockmann, K.L., Koschel, H., Bergmann, H. and Kühn, I. 1997) Nachhaltigkeit, Ordnungspolitik und freiwillige Selbstverpflichtung, Umwelt- und Ressourcenökonomie. Schriftenreihe für Europäische Wirtschaftsforschung. Physica Verlag, Heidelberg.

Reno, R.R., Cialdini, R.B. and Kallgren, C.A. (1993) The transsituational influence of social norms. Journal of Personality and Social Psychology, 64: 104-112.

Rothstein, R.N. (1980) Television feedback used to modify gasoline consumption. Behavior Therapy, 11: 683688.

Sabatier, P.A. and Pelkey, N. (1987) Incorporating multiple actors and guidance instruments into models of regulatory policymaking. An advocacy coalition framework. Administration and Society 19/2: 236-292.

SAEFL/Swiss Agency for the Environment, Forests, and Landscape (1997) Sustainable development in Switzerland: Strategy of the Federal Council. SAEFL, Bern.

Salamon, L.M. (1989) Beyond privatization. The tools of government action. The Urban Institute Press, Washington.

Schweizerische Bundeskanzlei (ed.) (1987) Geschäftsbericht des Bundesrates. Eidgenössische Drucksachenund Materialzentrale EDMZ, Bern.

SFSO/Swiss Federal Statistics Office and SAEFL/Swiss Agency for the Environment, Forests and Landscape (1997) The environment in Switzerland 1997 - Facts, Figures, Perspectives. SFSO and SAEFL, Bern. Online in the WWW: 〈http://www.buwal.ch/e/themen/umwelt $>$.

Skinner, B.F. (1969) Contingency and reinforcement. A theoretical analysis. Appleton-Century-Crofts, New York. 
Smith, E.R. and Mackie, D.M. (2000) Social psychology, 2nd edition. Psychology Press, Philadelphia.

Stavins, R.B. (2000) Experience with market-based environmental policy Instruments. In: Handbook of environmental economics, Mäler, K.-G. and Vincent, J. (eds.), North-Holland; forthcoming.

Stern, P.C. (2000a) Psychology and the science of human-environment interaction. American Psychologist, 55/5: 523-530.

Stern, P.C. (2000b) Toward a coherent theory of environmentally significant behavior. Journal of Social Issues, 56/3: 407-424.

Tiefbauamt des Kantons Bern, Oberingenieurkreis II (2000) Erfolgskontrolle bei Strassenbauprojekten am Beispiel der Seftigenstrasse (Köniz). Verkehrs- und umwelttechnische Auswirkungen und Überprüfung der Instrumente des Berner Modells. Arbeitspapier. Arbeitsgemeinschaft Planungsbüro Jürg Dietiker, Windisch, Künzler Bossert und Partner GmbH, Bern.

Tietenberg, T.H. (1990) Economic instruments for environement regulation. Oxford Review of Eoconomic Policy 6/1: 17-33.

Trebilcock, M.J., Hartle, D.G., Prichard, J.R.S., and Dewees, D.N. (1994) The choice of governing instruments. A study prepared for the Economic Council of Canada. Canadian Government Publishing Center, Ottawa.

Turner, K. and Oschor, H. (1994) Environmental economics and environmental policy instruments: Introduction and overview. In: Economic incentives and environmental policies: Principles and practice, Opschoor, J.B. and Turner, R.K. (eds.), Kluwer Academic Publisher, Dordrecht, Boston, London.

Ulli-Beer, S. and Haefeli, U. (1999) Evaluation der LEM-Partnerschaftsprojekte des Grossversuchs mit Leicht- und Elektromobilen in Mendrisio. Bericht über die Bevölkerungsbefragung 1997/1998 und 1999. Teil B: Auswertung und Analyse. IKAÖ, Universität Bern.

Vallender, K.A. (1990) Ziele und Instrumente des Schweizerischen Umweltrechts. In: Festschrift zum 65. Geburtstag von Mario M. Pedrazzini. Stämpfli and Cie, Bern.

Varone, F. (1998) Le choix des instruments des politiques publiques. Haupt, Bern.

Vedung, E. (1998) Policy instruments: Typologies and theories. In: Carrots, sticks and sermons. Policy instruments and their evaluation, Bemelmans-Videc, M.-L., Rist, R.C. and Vedung, E. (eds.), Transaction Publishers, New Brunswick, N.J.

Vedung, E. and van der Doelen, F.C.J. (1998) The sermon: Information programs in the public policy prosess - choice, effects, and evaluation. In: Carrots, sticks and sermons. Policy instruments and their evaluation, Bemelmans-Videc, M.-L., Rist, R.C. and Vedung, E. (eds.), Transaction Publishers, New Brunswick, N.J.

Wagstaff, M.C. and Wilson, B.E. (1988) The evaluation of litter behavior in a river environment. Journal of Environmental Education, 20: 39-44.

Wang, T.H. and Katzev, R.D. (1990) Group commitment and resource conservation: Two field experiments on promoting recycling. Journal of Applied Social Psychology, 20: 265-275.

Weber, M. (1904) Die Objektivität sozialwissenschaftlicher und sozialpolitischer Erkenntnis. Zitiert nach: Gesammelte Aufsätze zur Wissenschaftslehre, Tübingen, 3. Edition, 1968: 146-214.

Winett, R.A., Hatcher, J.W., Fort, T.R., Leckliter, I.N., Love, S.Q., Riley, A.W. and Fishback, J.F. (1982) The effects of videotape modeling and daily feedback on residential electricity conservation, home temperature and humidity, perceived comfort, and clothing worn: Winter and summer. Journal of Applied Behavior Analysis, 15: 381-402.

Winett, R.A., Leckliter, I.N., Chinn, D.E., Stahl, B. and Love, S.Q. (1985) Effects of television modeling on residential energy conservation. Journal of Applied Behavior Analysis, 18: 33-44.

Witmer, J.F. and Geller, E.S. (1976) Facilitating paper recycling: Effects of prompts, raffles, and contests. Journal of Applied Behavior Analysis, 9: 315-322.

Zimbardo, P.G. and Leippe, M.R. (1991) The psychology of attitude change and social influence. McGrawHill, New York. 
R. Kaufmann-Hayoz et al. 